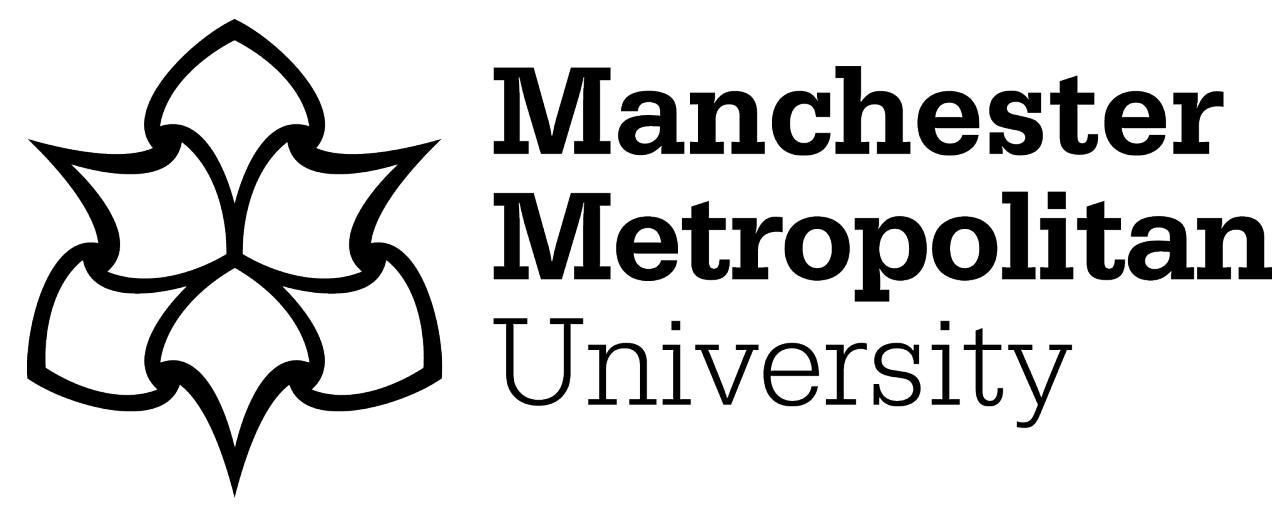

Tominaga, LKDG, Martins, VWB, Rampasso, IS, Anholon, R, Silva, D, Pinto, JS, Leal Filho, W and Lima Junior, FR (2020) Critical analysis of engineering education focused on sustainability in supply chain management: an overview of Brazilian higher education institutions. International Journal of Sustainability in Higher Education, 22 (2). pp. 380-403. ISSN 1467-6370

Downloaded from: https: //e-space.mmu.ac.uk/627234/

Version: Accepted Version

Publisher: Emerald

DOI: https://doi.org/10.1108//JSHE-01-2020-0002

Usage rights: Creative Commons: Attribution-Noncommercial 4.0

Please cite the published version 


\section{Critical analysis of engineering education focused on sustainability in supply chain management: an overview of Brazilian Higher Education Institutions}

Tominaga, L.K.G ${ }^{\mathrm{a}}$; Martins, V.W.B ${ }^{\mathrm{b}}$; Rampasso, I.S ; Anholon, R ${ }^{\mathrm{d}}$; Pinto, J.S ${ }^{\text {e; }}$ Silva, ${ }^{\text {f; }}$ Leal Filho, $W^{\text {g; }}$ Lima Junior, F.R. ${ }^{\text {h }}$

International Journal of Sustainability in Higher Education 01 Jan 2021 http://doi.org/10.1108/IJSHE-01-2020-0002

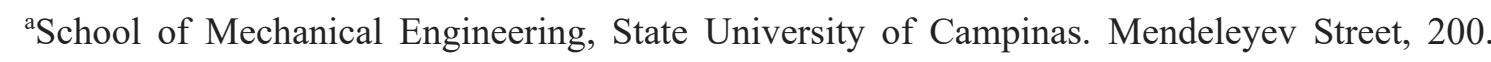
Campinas, São Paulo, Brazil. Phone: +55 19 3251-3492. e-mail: leonardokeiti@gmail.com

${ }^{\mathrm{b}}$ Department of Production Engineering, State University of Pará, Travessa Dr. Enéas Pinheriro, 2626. Belém, PA, Brazil. School of Mechanical Engineering, State University of Campinas. Mendeleyev Street, 200. Campinas, São Paulo, Brazil. Phone: +55 91 9309-2991.e-mail: vitor.martins@uepa.br

${ }^{\mathrm{c}}$ School of Mechanical Engineering, State University of Campinas. Mendeleyev Street, 200. Campinas, São Paulo, Brazil. PNPD/CAPES Program, Doctoral Program in Sustainable Management Systems. Federal Fluminense University. Passo da Pátria Street, 156. Niterói, Rio de Janeiro, Brazil. Phone: +55 19 3251-3312. e-mail: izarampasso@gmail.com

${ }^{\mathrm{d} S c h o o l}$ of Mechanical Engineering, State University of Campinas. Mendeleyev Street, 200. Campinas, São Paulo, Brazil. Phone: +55 19 3251-3312. e-mail: rosley@fem.unicamp.br

${ }^{e}$ Federal Institute of São Paulo, Bragança Paulista, São Paulo, Brazil. School of Mechanical Engineering, State University of Campinas. Mendeleyev Street, 200. Campinas, São Paulo, Brazil. Phone: +55 11 99918-3363. e-mail: jeffsouzap@gmail.com

${ }^{f}$ Laboratory of Innovation Technology Applied, Faculty of Education, State University of Campinas, Bertrand Russell Avenue, 801 Campinas, São Paulo, Brazil. Phone: +55 11 47028279. e-mail: dirceuds@gmail.com

${ }^{\mathrm{g}}$ Faculty of Life Sciences, Hamburg University of Applied Sciences, Ulmenliet 20, D-21033 Hamburg Germany. e-mail: walter.leal2@haw-hamburg.de

${ }^{\mathrm{h}}$ School of Management and Economics, Federal Technological University of Paraná, Brazil. Phone: +55 19 3310-4611, e-mail: eng.franciscojunior@gmail.com

Corresponding author: izarampasso@gmail.com 


\title{
Acknowledgements
}

This work was supported by the Coordenação de Aperfeiçoamento de Pessoal de Nível Superior - Brasil (CAPES) - Finance Code 001; process 88887.464433/2019-00; Conselho Nacional de Desenvolvimento Científico e Tecnológico (CNPq) 307536/2018-1; and 311530/2018-4; and Universidade do Estado do Pará (UEPA) 626/18.

Submitted: 02-Jan-2020

Revised: 08-Oct-2020

\begin{abstract}
Purpose: This research aims to critically analyze the engineering education focused on sustainability in supply chain management, in courses offered by Brazilian Higher Education Institutions.

Design/Methodology/Approach: Topics related to sustainable supply chain management were listed from the literature and used as a framework to gather professors' opinion on how well these topics are covered in engineering courses offered in Brazil. Data analysis was performed via frequency analysis and comparative ordering using the Fuzzy TOPSIS technique.

Findings: It was possible to evidence that most of the topics are superficially presented within other subjects and that there are few associated practical activities that enable a greater learning. Comparatively, issues related to ISO standards (related to quality and environmental management systems) and compliance with environmental laws, regulations and standards were highlighted. Additionally, it was possible to verify that there is a need for further study on issues related to energy efficiency, worker training and corporate governance.
\end{abstract}

Originality/Value: No similar study was found in the literature. The findings presented in this article can contribute to the improvement of engineering education in Brazil and other countries.

Keywords: Engineering education; Sustainability; Supply chain; Higher Education Institutions; Fuzzy TOPSIS. 


\section{Introduction}

In 2015, the United Nations set the 17 Sustainable Development Goals that are characterized as guidelines for a more sustainable future. These objectives are subdivided into 169 targets and many of them are directly associated with business context (D'Amato et al., 2019; Martins, Rampasso, et al., 2019; Pohlmann et al., 2019; UN, 2015). Consumer goods and services supply accordingly to the sustainability guidelines is one of the main challenges faced by companies, and there is a need to restructure their processes (Bradley et al., 2020; D’Amato et al., 2019; Doni et al., 2019; Martins, Anholon, et al., 2019; Pohlmann et al., 2019).

According to Bradley et al. (2020), sustainable supply of goods and services requires a combined use of new technologies, behavioral changes, and corporate business models changes. In this context, it is necessary to expand the debates about the desired features of new professionals training (Pérez-Foguet and Lazzarini, 2019; Stock and Kohl, 2018). UNESCO (2017) highlights that education for sustainable development addressed in SGD 4 - is essential for meeting the other 16 SDGs.

Vocational training for sustainable development is becoming an common practice in universities and it is being offered to students from several fields of knowledge (Avelar et al., 2019). Among these fields, engineering can be highlighted. This knowledge area has always been one of the most relevant areas for countries economy and development (Jabbour et al., 2015; Nyemba et al., 2019; Tang, 2018; Tejedor et al., 2018, 2019).

Despite the relevance of preparing engineers to work towards sustainable development (Zabaniotou et al., 2019), there are currently several challenges related to training new engineers in the context of sustainable development (Felgueiras et al., 2017; Moura et al., 2019; Rampasso et al., 2018; Stock and Kohl, 2018). Figueiró and Raufflet (2015) mention some of them, such as the difficulty to engage managers and professor in this new reality, a superficial understanding of the sustainability full concept and, finally, the ability to use new teaching methods and techniques that ensure the development of professional skills to meet sustainability guidelines. Additionally, as emphasized by Tejedor et al. (2018), transdisciplinary is an important aspect of sustainability. However, inserting transdisciplinarity skill in engineering students education is not an easy task.

Specifically in Brazil, it should be mentioned that debates on new forms of engineering education are gaining relevance. However, much remains to be done in this 
regard (Rampasso, Siqueira, et al., 2019). In this line of reasoning, Rampasso et al. (2018) validated difficulties to insert sustainability in the engineering education promoted by Brazilian HEIs, both in the planning phase of the initiatives and in the didactic practice, according to the perception of teachers who develop initiatives in this direction. Moreover, they proved that there is a causal relationship between these practices, that is, if there are problems in the planning phase, problems will be evidenced in the didactic practice. In a complementary way, Rampasso, Siqueira, et al. (2019) also analyzed students' perceptions regarding the difficulties of inserting sustainability in the engineering courses offered in Brazil. Among the evaluated difficulties, the students highlighted the following problems: "sustainable issues debated only in specific disciplines in a limited extend; difficulty to integrate disciplines for the broad teaching of sustainability; lack of practical and real examples of how sustainability can be embedded in the specific context of the course; activities and examples presented focus exclusively on environmental issues" (Rampasso, Siqueira, et al., 2019).

These difficulties presented by Brazilian HEIs to insert sustainability in engineering education present consequences. Analyzing a sample of Brazilian engineering students, Rampasso, Anholon, et al. (2019) verified deficiencies in engineering students knowledge about sustainability issues. In the National Curriculum Guidelines of the Engineering Undergraduate Course, Brazilian Ministry of Education recognizes the need of Brazilian HEIs to prepare engineering students to acts towards sustainable development (Brazil, 2019).

However, an interesting issue in the mentioned document is that even in some items that are not addressing sustainable development, it is possible to observe skills required for professionals to consider this concept in their actions, such as the need to have a holistic and humanistic view, being creative, present an ethical behavior, among others. That is, analyzing this document, it is possible to note that sustainable development does not need to clearly being debated for HEIs to develop future engineers to work for it (Brazil, 2019).

Since many of the activities developed by engineers in companies are related to supply chain management, it is important to discuss the inclusion of sustainability in the teaching of subjects related to the theme. According to Ballou (2004), supply chain management aims to add value to the end consumer by developing a set of activities such as transportation, inventory control and warehousing, which routinely repeat themselves 
along the supply channel turning inputs into finished products. Fritz et al. (2017) argue that there are many aspects associated with sustainability that should be addressed in supply chain management.

However, despite the relevance of this theme, the literature about preparing Brazilian engineering students to work towards sustainable development is scarce. Therefore, according to the context presented and its importance, this research aimed to understand how the aspects of sustainability in supply chain management are being addressed in engineering education by Brazilian Higher Education Institutions (HEI). Despite being characterized as an exploratory study, the results presented here can contribute to broaden the debates about the new profile of engineers focused on the market based on sustainability aspects.

In addition to this introductory section, the article features five additional sections. Section 2 presents the theoretical basis to better explain the context of this study. Section 3 addresses the methodological procedures used to achieve the results, allowing other researchers to replicate the research. Section 4 presents the results achieved with the survey. Section 5 presents the associated debates relating the results to the literature. Finally, section 6 brings the final considerations and conclusions of the study, followed by the list of references considered in this research.

\section{Theoretical base}

This section presents the theoretical basis to better explain the context of this study. Aspects of sustainability insertion in higher education and sustainability in supply chain management are addressed.

\subsection{Sustainability insertion in higher education}

HEIs around the world are increasingly developing skills and raising awareness among their students on topics related to sustainability, aiming to guarantee economic development where it is also possible to jointly address social and environmental aspects (Corrêa et al., 2020). In this sense, HEI are considered key agents to train business leaders to consider sustainability issues. Through the teaching dynamics, these institutions should consider the so-called education for sustainability (Singh and Segatto, 2020a). 
According to Figueiró and Raufflet (2015), sustainability has received an increasing attention in management education over the past ten years. Through a literature review, the authors point out that although most articles present the need to change curricula, few specify how this change could and would be achieved by designing the course or explicit educational paradigms to meet the training requirements in the context of education. sustainability. Additionally, the authors argue that sustainability is a comprehensive concept, with broad definitions and that, therefore, the limited clarity around its introduction in education reflects in more superficial and broad debates on the subject. Singh and Segatto (2020b) corroborate saying that the demand for training professionals concerned with sustainability issues has made HEI concerned with the development of skills focused on the social, environmental and economic dimensions of their students.

Anastasiadis et al. (2020) they highlight that sustainability is among the main challenges in higher education since it plays a vital role in supporting the implementation of sustainability initiatives in several professional areas. The authors argue that there has been considerable progress in higher education to address this reality, with an emphasis on introducing sustainability concepts into courses through existing literature and detailing case studies on sustainability education and mapping students' perceptions of their learning in this context.

According to Moura et al. (2019), many - HEI are already developing activities focused on sustainability, following the concept of the triple bottom line created by Elkington (1997), that is, considering the environmental, economic and social aspects. These authors emphasize that in universities, this traditional view is usually segmented in education, research, university operations, external community and reports. Additionally Aleixo et al. (2018) say HEI are developing sustainability practices as part of their educational intervention.

Therefore, in recent years it has been possible to notice significant changes in the way of teaching in several HEIs about meeting the promotion of discussions on aspects of sustainability. Many of these changes appear as a reflection of the reconfiguration of society expectations regarding the social, cultural and economic roles and functions of higher education (José Sá, 2020). In education for sustainable development, the development of key transversal skills for sustainability are relevant to the achievement of sustainable development goals in a different way (UNESCO, 2017). Considering the role 
played by engineers in society (Rampasso et al., 2018), as highlighted by Raoufi et al. (2019), changes in engineering education must be made.

However, there are few examples in the literature about sustainability insertion in engineering courses. Focusing on Brazilian reality, the action research reported by Rampasso, Anholon, Silva, Cooper Ordóñez, et al. (2019) should be highlighted. In this study, sustainability aspects related to operations management are presented to mechanical engineering students of a Brazilian university. Thus, besides technical aspects related to engineers routine tasks, students are stimulated to consider social and environmental positive and negative impacts of their actions instead of considering only economic performance.

Considering the relevance of inserting sustainability in higher education, engineering students need to be taught about it considering entire supply chains.

\subsection{Sustainability in Supply Chain Management}

In the last four decades, supply chain management has been developed through strategic alignment and integration of business chain processes to all stages, aiming to meet customers demand with quality and in a timely manner. These processes involve the development of logistics, purchasing, marketing and manufacturing activities. In this sense, strategic supply chain planning needs to be aligned with responsiveness, customer focus and sustainable practices (Khan and Qianli, 2017).

The insertion of sustainability concepts in supply chain management field is widely debated in the literature (Jalilian and Mirghafoori, 2020; Vanalle et al., 2017). Dubey et al. (2017) state that the literature fails in properly understanding the concept of sustainable supply chain both from a theoretical and managerial point of view, with overlaps among the green supply chain management literature, environmental supply chain management and sustainable supply chain literature, as well as other areas that have attracted products, such as environmental supply chains, ethical supply chains and responsible supply chains.

For Jalilian and Mirghafoori (2020), a sustainable supply chain need to consider environmental and social negative impacts throughout the chain and, for social impacts assessment, different kinds of stakeholders need to be considered, from customers to government. Shokouhyar et al. (2019) highlights that in a sustainable supply chain 
positive economic results are still a core target, however, social and environmental impacts also need to be considered. For this, integration among supply chain links is required, which implies in cooperation, trust and coordination among them. For this integration, as emphasized by Chiappetta Jabbour et al. (2020) and Shokouhyar et al. (2019), technologies related to Industry 4.0 can be valuable tools.

Ahi and Searcy (2013), analyzing definitions of green supply chain management and sustainable supply chain management, verified, in 2013, 22 definitions of the first term and 12 definitions of the second term. For these authors, sustainable supply chain management is an extension of green supply chain management concept, since the later does not consider economic and social aspects. This finding can also be observed in several definitions of green supply chain management in more recent literature. According to Quintana-García et al. (2020), green supply chain management is related to monitoring environmental performance throughout a supply chain. According to these authors, a proper green supply chain management positively contribute to corporate reputation. Additionally, Fritz (2019) defines sustainable supply chain management as a supply chain management that integrates sustainability objectives and requirements defined by the company, suppliers, customers and external stakeholders.

Recently, circular economy concept also started to be related with sustainable supply chain. Circular economy requires greater reduction, reutilization and recycling throughout products lifecycle to minimize negative environmental impacts. Consequently, it makes companies to survive in a more challenging environment. In this context, organizations need to be flexible, as well as their supply chain management. In this line of reasoning, the literature emphasizes the contribution of sustainable supply chain flexibility to enhance companies meeting goals related to circular economy (Bai et al., 2019).

Fritz et al. (2017), performing an extensive literature review, argue that there are many aspects associated with sustainability that should be addressed in supply chain management, including stakeholders related issues, materials disposal, greenhouse gas emissions and carbon footprint, energy use, corporate governance, corporate social responsibility, suppliers sustainability performance evaluation, among others.

Observing these aspects, it is possible to notice that engineers can and should be involved in all of them. For example, Schöggl et al. (2017) highlight the importance of eco-design to achieve sustainable goals, since its concept guides several aspects 
highlighted above (reuse and proper destination of materials, use of renewable materials, energy from renewable sources, among others). Zizka et al. (2021) also emphasize the role of engineering activities in ethical, social and environmental aspects. And the relevance of engineering field in education for sustainable development has also being emphasized in the literature (Quelhas et al., 2019).

In this sense, the role of the productive systems management engineer involved with supply chain management becomes essential for the achievement of sustainable objectives and, consequently, the guarantee of business competitiveness.

\section{Methodological Procedures}

The present research was developed through 5 well-defined stages, being the same ones presented in Figure 1 and discussed below.

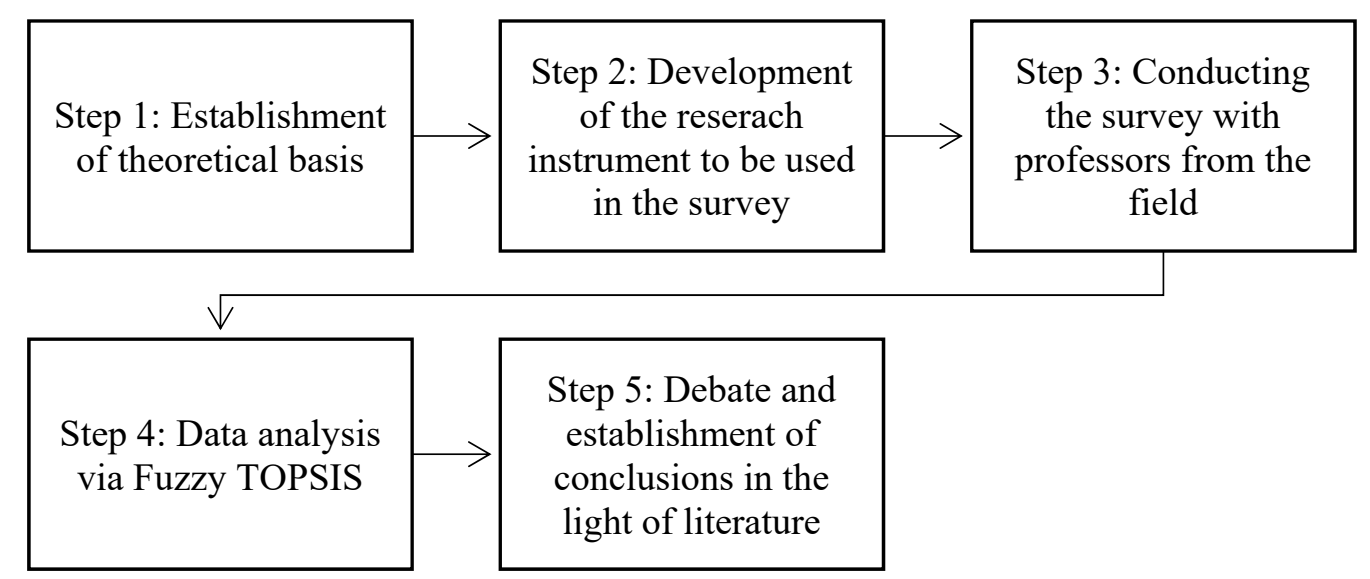

Figure 1. Steps followed in this research (Source: Authors)

\section{a) Establishment of theoretical basis}

To establish the theoretical basis about sustainability in higher education, new forms of teaching and the sustainability in supply chain management, the authors of this article performed a literature review. Combinations of the following terms were used: "Insertion”, "sustainability”, "Higher Education”, “Green”, "Sustainable”, "Supply Chain", "Management", "engineering education". The following databases were used to perform the research: "Emerald Insight", "Science Direct", "Taylor \& Francis" and "Springer". It should be mentioned that authors also searched for papers that described 
Fuzzy TOPSIS (Technique for Order Preference by Similarity to Ideal Solution) technique according to the guidelines of Chen (2000).

\section{b) Structuring of the research instrument and survey application}

The research instrument used in the survey was composed of two parts. The first one was dedicated to respondents' characterization regarding their professional training background, the engineering courses in which they give classes on supply chain management, their experience time in the field, among other information. The second part, for its turn, was directly associated to the focus of this study. From the research of Fritz et al. (2017), it was defined 20 topics to be evaluated and, for each topic, codes were defined to facilitate their identification. Table 1 presents this information. It is worth mentioning that Fritz et al. (2017) present details of other studies and summarizes the content discussed here. Aiming at a better operationalization of the survey, without losing content from Fritz et al. (2017), the authors carried out the grouping of similar topics, thus enabling the maintenance of the general concept; for example, the items "Prohibition of child labor" and "[Compliance] With social standards, regulations, and laws" were considered within v12 (Compliance with laws, regulations and social standards), since in Brazil, child labor is against the law This summarization contemplates all the issues addressed by Fritz et al. (2017). Therefore, the use of Fritz et al. (2017) to base the analyzed items was due to the relevance and robustness of the publication, which enabled a proper operationalization of the survey developed in this research. To show the robustness of the model, a comparison can be made with the framework proposed by Dubey et al. (2017), in this framework, named World Class Sustainable Supply Chain Management, six constructs (Environmental, Social Values and Ethics, Economic Stability, Operational Performance Assessment, Internal Factors, External Factors) were proposed. The model of Fritz et al. (2017) contemplates most of these topics.

Table 1. Topics of the second part of the questionnaire and codes for each variable. (Sourrce: Adapted from Fritz et al. (2017)).

\begin{tabular}{cl}
\hline Code & \multicolumn{1}{c}{ Definition } \\
\hline v1 & Definition and assessment of all stakeholder requirements \\
v2 & Preventing use, reuse, collection, separation, recovery, and proper disposal of materials. \\
v3 & Use of renewable materials \\
v4 & Reduction and prevention of greenhouse gas emissions / carbon footprint \\
v5 & Energy efficient products and services and promotion of initiatives to reduce indirect energy \\
\hline
\end{tabular}




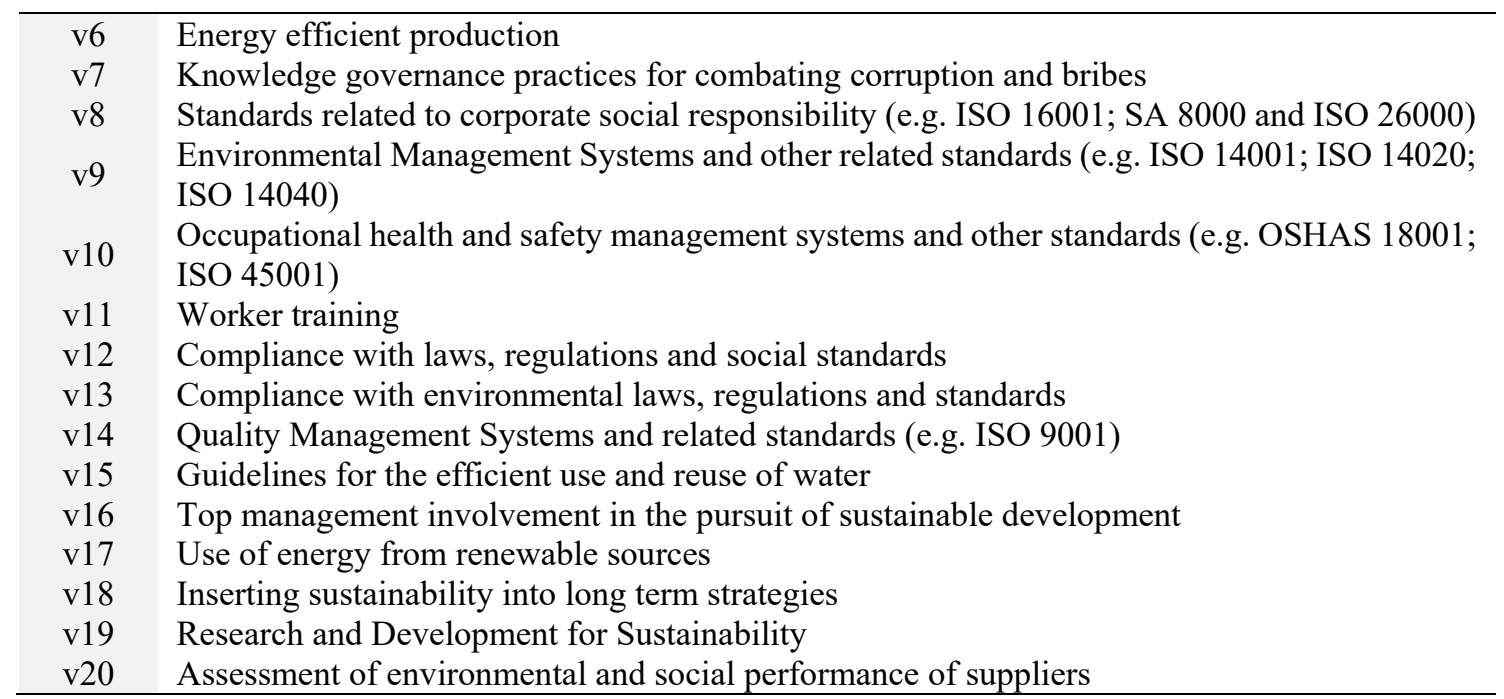

For each topic presented in Table 1, respondents should give a score from 1 to 5, and their meanings are presented in Table 2. It should be noted that these scores designate evolutionary stages and, thus, can also be understood as linguistic variables.

Table 2. Meaning of the scores used in the questionnaire (Source: Authors).

\begin{tabular}{cl}
\hline Note & \multicolumn{1}{c}{ Meaning of the scores } \\
\hline Score 1 & The aspect is not contemplated. \\
Score 2 & The aspect is superficially contemplated within other subjects. \\
Score 3 & The aspect is covered within other subjects, with attention being paid to it. \\
Score 4 & The aspect is fully covered in engineering courses in Brazil, providing students with theoretical knowledge. \\
Score 5 & $\begin{array}{l}\text { The aspect is fully covered in engineering courses in Brazil, providing students with theoretical and practical } \\
\text { knowledge. }\end{array}$ \\
\hline
\end{tabular}

In Brazil, every research involving human beings requires the consideration of an ethics committee, according to Resolution 466/2012 of the Ministry of Health. Thus, the project of this study and the research instrument were presented to the Ethics Committee of the University. The survey was initiated after the Committee's approval. 


\section{c) Survey}

Data collection was performed for two months. During this period, invitations were made for professors that give or already gave classes related to supply chain management and that know the reality of Brazilian HEIs. In the end, 34 answered questionnaires were received and used in this research. Considering the number of respondents obtained in the survey, it is worth mentioning that a statistical analysis was not performed, but through the use of a multicriteria decision technique that does not have a minimum sample restriction, as detailed below. In addition, it is also important to highlight the exploratory nature of the research where, by means of a non-probabilistic sample, although the results cannot be generalized, the findings contribute to the literature, showing improvement opportunities for Brazilian reality and generating debates to enhance the literature.

\section{d) Data analysis}

Initially, collected data were analyzed in relation to the answers' frequencies and, posteriorly, via Fuzzy TOPSIS technique. The TOPSIS technique was developed by Hwang and Yoon in 1981 and is characterized as a technique to support multicriteria decision making (Akram et al., 2020). Chen (2000) proposed an extension of this technique, in which linguistic variables are represented by fuzzy numbers. This extension has being used for researchers from different knowledge fields (Akram et al., 2020; Doukas and Nikas, 2020). It is noteworthy that the technique allows to smooth the inherent uncertainties in the responses collected in the survey and consequently guarantees greater robustness in the validation of the results.

Generally, Fuzzy TOPSIS technique application of this article followed the guidelines of Chen (2000). Some minor modifications were made since the main objective was characterized by the ordering of the topics (variables) presented in Chart 1 weighted by the respondents' experience levels.

To obtain the fuzzy grades presented in Chart 2, it was chosen a triangular function, in which each score and its respective transitions could be represented by three numbers. Chart 1 shows the fuzzy grades used in this study. 
Chart 1. Fuzzy grades (Source: Authors)

\begin{tabular}{|c|c|c|c|}
\hline Grade 1 & 0.00 & 0.00 & 0.25 \\
\hline Grade 2 & 0.00 & 0.25 & 0.50 \\
\hline Grade 3 & 0.25 & 0.50 & 0.75 \\
\hline Grade 4 & 0.50 & 0.75 & 1.00 \\
\hline Grade 5 & 0.75 & 1.00 & 1.00
\end{tabular}

To obtain a triangular fuzzy number for respondents' experience level, it was opted for three evolutionary levels (E1, E2 and E3). In this sense, E1 represents a low experience level, E2 is for an intermediate level, and E3 represents a high level of experience. It worth mentioning that the allocation of respondents at the three levels above was based on information provided by participants and information available on the Lattes Curriculum platform (Brazilian database that provides information on academics). Since the longest experience observed was 40 years, the values $[0 ; 20 ; 40]$ were used as the first parameters for triangular fuzzy, which normalized the structure presented in Chart 2.

Chart 2. Fuzzy experience levels (Source: Authors)

\begin{tabular}{|c|c|c|c|c|}
\hline Level E1 & 0.00 & 0.00 & 0.50 \\
\cline { 1 - 3 } Level E2 & 0.00 & 0.50 & 1.00 \\
\hline Level E3 & 0.50 & 1.00 & 1.00 &
\end{tabular}

Respondents classified at level E3, for example, have more than 20 years of experience, who have a high level of education (doctorate) and who are intensely involved with initiatives to insert sustainability in supply chain management disciplines. Uncertainties related to respondents' allocation into the levels are expected, but this is the reason why the Fuzzy TOPSIS technique was chosen for data analysis.

Once triangular fuzzy data were defined, calculation was done according to the recommendations of Chen (Chen, 2000). These recommendations are presented in six steps:

Step 1: To structure the matrix that presents the grades measured for each variable by the respondents (matrix $\tilde{G}$ ) and to present the matrix that represents the respondents' experience level (matrix $\tilde{E}$ ). These matrices are presented below. 


$$
\begin{gathered}
\tilde{G}=\left[\begin{array}{cccc}
\tilde{\mathrm{x}}_{11} & \tilde{\mathrm{x}}_{12} & \ldots & \widetilde{\mathrm{x}}_{1 n} \\
\tilde{\mathrm{x}}_{21} & \widetilde{\mathrm{x}}_{22} & \ldots & \widetilde{\mathrm{x}}_{2 n} \\
\ldots & \ldots & \ldots & \ldots \\
\widetilde{\mathrm{x}}_{m 1} & \widetilde{\mathrm{x}}_{m 2} & \ldots & \widetilde{\mathrm{x}}_{m n}
\end{array}\right] ; \widetilde{\mathrm{x}}_{i j}=\left[a_{i j}, b_{i j}, c_{i j}\right] \rightarrow \text { fuzzy grade inputs; (Matrix 1) } \\
\tilde{E}=\left[\widetilde{w}_{1}, \widetilde{w}_{2}, \ldots . \widetilde{w}_{n}\right] ; \widetilde{w}_{j}=\left[w_{1}, w_{2}, w_{3}\right] \rightarrow \text { fuzzy experience inputs; (Matrix 2) }
\end{gathered}
$$

Step 2: To normalize matrix $\tilde{G}$ to obtain a matrix $\tilde{R}$ (matrix 3 ). Specifically in this study, the scores are understood as "benefits", according to Chen (Chen, 2000) denomination; thus, the normalization is obtained through Equation 1.

$$
\tilde{R}=\left[\tilde{r}_{i j}\right]_{m \times n}\left(\text { Matrix 3); } \tilde{r}_{i j}=\left(\frac{a_{i j}}{C_{J}^{*}}, \frac{b_{i j}}{C_{J}^{*}}, \frac{c_{i j}}{C_{J}^{*}},\right) \text {, in which } C_{J}^{*}=\max (\mathrm{i}) c_{i j} \quad\right. \text { (Equation 1); }
$$

Step 3: Considering that the answers are weighted through the respondents' level of experience, it is necessary to obtain a matrix $\tilde{V}$ (Matrix 4). It is obtained by multiplying the normalized fuzzy responses by the respective fuzzy and normalized respondents' experience levels.

$$
\tilde{V}=\left[\tilde{v}_{i j}\right]_{m \times n} \rightarrow \mathrm{i}=1,2, \ldots \mathrm{m} ; \mathrm{j}=1,2, \ldots \mathrm{n} \rightarrow \text { in which } \tilde{v}_{i j}=\tilde{r}_{i j}(.) \widetilde{w}_{j} \quad \text { (Matrix 4) }
$$

Step 4: Once obtained the fuzzy, normalized and weighted matrix (matrix $\tilde{V}$ ), it is possible to calculate the distance of each element from the positive and negative ideal solutions. The positive ideal solution, the negative ideal solution and the equation to calculate the distances are presented below.

$$
\begin{gathered}
\mathrm{d}(\tilde{m}, \tilde{n})=\sqrt{\frac{1}{3}\left[\left(m_{1}-n_{1}\right)^{2}+\left(m_{2}-n_{2}\right)^{2}+\left(m_{3}-n_{3}\right)^{2}\right]} \quad \text { (Equation 2) } \\
A^{*}=\left[\tilde{v}_{1}^{*}, \tilde{v}_{2}^{*}, \tilde{v}_{3}^{*}\right] \text { where, } \tilde{v}_{j}^{*}=[1,1,1] \rightarrow \text { positive ideal solution; (Matrix 5) } \\
A^{-}=\left[\tilde{v}_{1}^{-}, \tilde{v}_{2}^{-}, \tilde{v}_{3}^{-}\right] \text {where, } \tilde{v}_{j}^{-}=[0,0,0] \rightarrow \text { negative ideal solution; (Matrix 6) }
\end{gathered}
$$

Step 5: The total distance of each alternative in relation to positive and negative ideal solutions is provided by the sum of partial distances obtained in the previous phase, as it 
is showed by Equations 3 and 4. It worth mentioning that, in this research, the alternatives are the analyzed variables.

$$
\begin{aligned}
& d_{i}^{*}=\sum_{j=1}^{n} d\left(\tilde{v}_{i j}, \tilde{v}_{j}^{*}\right) \rightarrow \text { total distance from the positive solution (Equation 3) } \\
& d_{i}^{-}=\sum_{j=1}^{n} d\left(\tilde{v}_{i j}, \tilde{v}_{j}^{-}\right) \rightarrow \text { total distance from the negative solution (Equation 4) }
\end{aligned}
$$

Step 6: Finally, the closeness coefficient $\left(\mathrm{CC}_{\mathrm{i}}\right)$ of each alternative can be calculated using the equation presented below. The best ranked alternative will be considered the one with the highest value of $\mathrm{CC}_{\mathrm{i}}$.

$$
C C_{i}=\frac{d_{i}^{-}}{\left(d_{i}^{*}+d_{i}^{-}\right)} \rightarrow \text { Closeness coefficient (Equation 5) }
$$

\section{e) Results debates and conclusion}

Based on the results obtained through the data analysis described in the previous step, debates could be held in the light of the literature and the establishment of conclusions was made. It is important to highlight that to perform a critical analysis of research findings and enhance the debates, the authors studied punctually the best and worst ranked themes, consulting additional references for these specific themes.

\section{Results}

As previously mentioned, this section presents the results obtained and associated debates. Initially, the responses collected from the 34 professors were tabulated and grouped according to experience levels E1, E2 and E3, as presented in Table 3. 
Table 3. Responses collected and tabulated according to experience classes E1, E2 and E3 (Source:

Authors).

\begin{tabular}{|c|c|c|c|c|c|c|c|c|c|c|c|c|c|c|c|c|c|c|c|c|c|}
\hline Resp. & v1 & v2 & v3 & $\mathrm{v} 4$ & v5 & v6 & $\mathrm{v7}$ & v8 & v9 & v10 & v11 & $\mathrm{v} 12$ & V13 & v14 & $\mathrm{v} 15$ & v16 & v17 & v18 & v19 & v20 & Experience \\
\hline R1 & 1 & 3 & 3 & 2 & 1 & 2 & 1 & 2 & 5 & 2 & 2 & 2 & 4 & 5 & 2 & 2 & 2 & 1 & 2 & 3 & E1 \\
\hline $\mathrm{R} 2$ & 3 & 4 & 4 & 4 & 4 & 4 & 2 & 2 & 3 & 3 & 2 & 2 & 2 & 4 & 4 & 4 & 4 & 3 & 3 & 4 & E1 \\
\hline $\mathrm{R} 3$ & 2 & 2 & 2 & 2 & 2 & 3 & 2 & 2 & 2 & 2 & 3 & 2 & 2 & 2 & 2 & 2 & 2 & 2 & 2 & 2 & E1 \\
\hline $\mathrm{R} 4$ & 2 & 1 & 2 & 2 & 2 & 2 & 1 & 2 & 2 & 2 & 1 & 2 & 2 & 2 & 2 & 2 & 2 & 2 & 2 & 2 & E1 \\
\hline R5 & 3 & 2 & 1 & 2 & 1 & 2 & 1 & 1 & 2 & 2 & 3 & 3 & 2 & 4 & 2 & 3 & 2 & 1 & 2 & 1 & E1 \\
\hline R6 & 3 & 2 & 2 & 3 & 2 & 2 & 2 & 2 & 3 & 3 & 3 & 2 & 3 & 4 & 2 & 3 & 2 & 2 & 3 & 3 & E1 \\
\hline R7 & 2 & 2 & 3 & 2 & 3 & 3 & 2 & 2 & 3 & 4 & 3 & 2 & 2 & 3 & 2 & 2 & 2 & 2 & 3 & 2 & E1 \\
\hline R8 & 3 & 3 & 2 & 2 & 3 & 2 & 2 & 2 & 2 & 2 & 3 & 2 & 2 & 2 & 4 & 3 & 2 & 3 & 3 & 3 & E1 \\
\hline R9 & 4 & 3 & 4 & 4 & 3 & 3 & 2 & 3 & 3 & 3 & 4 & 4 & 4 & 5 & 3 & 3 & 3 & 3 & 3 & 3 & E1 \\
\hline $\mathrm{R} 10$ & 3 & 3 & 3 & 2 & 2 & 2 & 3 & 4 & 4 & 4 & 3 & 3 & 3 & 4 & 2 & 4 & 3 & 4 & 4 & 3 & E1 \\
\hline R11 & 5 & 3 & 4 & 4 & 4 & 4 & 2 & 2 & 5 & 4 & 3 & 4 & 5 & 5 & 4 & 4 & 4 & 5 & 5 & 4 & E2 \\
\hline $\mathrm{R} 12$ & 4 & 4 & 2 & 1 & 1 & 4 & 1 & 4 & 4 & 2 & 5 & 4 & 4 & 4 & 4 & 4 & 3 & 4 & 4 & 4 & E2 \\
\hline R13 & 2 & 3 & 2 & 3 & 3 & 2 & 1 & 2 & 4 & 2 & 1 & 3 & 4 & 4 & 2 & 2 & 3 & 2 & 2 & 2 & E2 \\
\hline R14 & 2 & 4 & 3 & 2 & 2 & 2 & 2 & 3 & 3 & 1 & 1 & 2 & 3 & 2 & 2 & 2 & 2 & 4 & 4 & 3 & E2 \\
\hline R15 & 2 & 3 & 3 & 3 & 3 & 3 & 2 & 2 & 3 & 3 & 2 & 2 & 3 & 3 & 3 & 2 & 3 & 2 & 2 & 2 & E2 \\
\hline R16 & 3 & 2 & 1 & 1 & 1 & 2 & 1 & 3 & 3 & 3 & 2 & 3 & 3 & 4 & 1 & 2 & 1 & 1 & 1 & 1 & E2 \\
\hline R17 & 3 & 3 & 3 & 2 & 2 & 2 & 2 & 3 & 3 & 4 & 2 & 3 & 3 & 5 & 3 & 3 & 3 & 3 & 3 & 3 & E2 \\
\hline R18 & 3 & 4 & 3 & 4 & 3 & 3 & 3 & 4 & 3 & 3 & 3 & 3 & 3 & 4 & 4 & 4 & 4 & 4 & 4 & 3 & E2 \\
\hline R19 & 5 & 4 & 4 & 4 & 2 & 2 & 3 & 3 & 3 & 3 & 5 & 5 & 5 & 5 & 4 & 4 & 4 & 5 & 4 & 5 & E2 \\
\hline $\mathrm{R} 20$ & 3 & 4 & 3 & 3 & 2 & 3 & 2 & 3 & 3 & 3 & 2 & 3 & 3 & 4 & 2 & 3 & 2 & 4 & 4 & 3 & E2 \\
\hline R21 & 5 & 4 & 4 & 4 & 3 & 2 & 1 & 3 & 5 & 3 & 4 & 4 & 4 & 5 & 3 & 4 & 3 & 4 & 3 & 5 & E2 \\
\hline R22 & 2 & 3 & 3 & 2 & 2 & 3 & 4 & 3 & 3 & 3 & 3 & 3 & 3 & 3 & 3 & 3 & 2 & 2 & 2 & 2 & E2 \\
\hline R23 & 2 & 2 & 2 & 2 & 2 & 1 & 1 & 1 & 3 & 2 & 2 & 3 & 3 & 3 & 2 & 1 & 2 & 2 & 2 & 2 & E2 \\
\hline R24 & 5 & 5 & 5 & 3 & 3 & 5 & 3 & 3 & 5 & 5 & 5 & 5 & 3 & 5 & 5 & 5 & 3 & 5 & 3 & 5 & E2 \\
\hline $\mathrm{R} 25$ & 2 & 2 & 2 & 3 & 3 & 3 & 1 & 2 & 2 & 2 & 1 & 2 & 3 & 2 & 2 & 2 & 4 & 3 & 4 & 1 & E2 \\
\hline R26 & 2 & 4 & 2 & 1 & 2 & 2 & 1 & 2 & 4 & 2 & 1 & 2 & 3 & 4 & 2 & 2 & 3 & 3 & 2 & 3 & E3 \\
\hline R27 & 4 & 3 & 2 & 2 & 2 & 2 & 2 & 3 & 4 & 4 & 3 & 4 & 4 & 5 & 4 & 3 & 4 & 4 & 3 & 2 & E3 \\
\hline R28 & 2 & 1 & 2 & 2 & 2 & 2 & 1 & 2 & 2 & 2 & 2 & 1 & 2 & 3 & 1 & 2 & 2 & 1 & 1 & 2 & E3 \\
\hline R29 & 3 & 3 & 2 & 2 & 3 & 3 & 2 & 3 & 4 & 4 & 2 & 3 & 4 & 4 & 2 & 2 & 2 & 2 & 2 & 2 & E3 \\
\hline R30 & 2 & 2 & 2 & 2 & 2 & 3 & 2 & 3 & 3 & 2 & 2 & 2 & 2 & 3 & 1 & 1 & 2 & 2 & 2 & 2 & E3 \\
\hline R31 & 1 & 3 & 2 & 4 & 3 & 3 & 1 & 1 & 3 & 1 & 1 & 1 & 1 & 1 & 2 & 1 & 1 & 4 & 1 & 4 & E3 \\
\hline R32 & 3 & 3 & 4 & 4 & 3 & 3 & 2 & 3 & 3 & 3 & 3 & 2 & 2 & 3 & 3 & 3 & 3 & 3 & 3 & 3 & E3 \\
\hline R33 & 2 & 3 & 3 & 2 & 3 & 2 & 1 & 1 & 3 & 2 & 2 & 4 & 4 & 4 & 2 & 2 & 2 & 1 & 1 & 1 & E3 \\
\hline R34 & 2 & 3 & 2 & 2 & 3 & 3 & 1 & 4 & 4 & 3 & 3 & 3 & 3 & 4 & 2 & 3 & 2 & 2 & 2 & 2 & E3 \\
\hline
\end{tabular}

Initially, a frequency analysis was performed for each group of respondents (E1, E2 and E3) in order to identify where the majority of the responses were concentrated and if, broadly, it was possible to notice divergences among the presented opinions. Tables 4,5 and 6 show these frequencies, with the highest frequencies noted in red. When the frequency for one of the scores was $50 \%$ or higher, only the score stood out. Otherwise, the two highest frequencies were highlighted. In the case of ties, three frequencies were highlighted.

Table 4. Frequency analysis of responses from group E1 (Source: Authors)

\begin{tabular}{|c|c|c|c|c|c|c|c|c|c|c|c|c|c|c|c|c|c|c|c|c|}
\hline Grac & v1 & v2 & v3 & $\mathrm{v} 4$ & v5 & v6 & v7 & v8 & v9 & v10 & v11 & v12 & v13 & v14 & v15 & v16 & v17 & v18 & v19 & v20 \\
\hline N1 & $10.0 \%$ & 10.0 & $10.0 \%$ & $0.0 \%$ & $.0 \%$ & $0.0 \%$ & $30.0 \%$ & $10.0 \%$ & $0.0 \%$ & $0.0 \%$ & te & $0.0 \%$ & $0.0 \%$ & encto & $0.0 \%$ & $0.0 \%$ & $0.0 \%$ & 20.070 & $0.0 \%$ & $.0 \%$ \\
\hline N2 & $30.0 \%$ & .... & $40.0 \%$ & $70.0 \%$ & $40.0 \%$ & $60.0 \%$ & $60.0 \%$ & $70.0 \%$ & $40.0 \%$ & $50.0 \%$ & $20.0 \%$ & $70.0 \%$ & $60.0 \%$ & $30.0 \%$ & & $40.0 \%$ & $70.0 \%$ & & $40.0 \%$ & $30.0 \%$ \\
\hline N3 & $=0$ & $40.0 \%$ & $30.0 \%$ & $10.0 \%$ & & $30.0^{\circ}$ & 10. & 1000 & 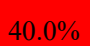 & 30 & 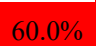 & $20.0 \%$ & 20 & $\%$ & 100 & $40.0 / 0$ & $20.0 \%$ & & $\%$ & nos \\
\hline N4 & 10.070 & $10.0 \%$ & $20.0 \%$ & $20.0 \%$ & $10.0 \%$ & $10.0 \%$ & $0.0 \%$ & $10.0 \%$ & $10.0 \%$ & $20.0 \%$ & $10.0 \%$ & $10.0 \%$ & $20.0 \%$ & & $20.0 \%$ & $20.0 \%$ & $10.0 \%$ & $10.0 \%$ & $10.0 \%$ & $10.0 \%$ \\
\hline N5 & $0.0 \%$ & $0.0 \%$ & $0.0 \%$ & $0.0 \%$ & $0.0 \%$ & $0.0 \%$ & $0.0 \%$ & $0.0 \%$ & $10.0 \%$ & $0.0 \%$ & $0.0 \%$ & $0.0 \%$ & $0.0 \%$ & & $0.0 \%$ & $0.0 \%$ & $0.0 \%$ & $0.0 \%$ & $0.0 \%$ & $0.0 \%$ \\
\hline
\end{tabular}


Table 5. Frequency analysis of responses from group E2 (Source: Authors)

\begin{tabular}{|c|c|c|c|c|c|c|c|c|c|c|c|c|c|c|c|c|c|c|c|c|}
\hline Grade & v1 & v2 & v3 & $\mathrm{v4}$ & v5 & v6 & v7 & v8 & v9 & v10 & v11 & v12 & v13 & v14 & v15 & v16 & v17 & v18 & v19 & v20 \\
\hline N1 & $0.0 \%$ & $0.0 \%$ & $6.7 \%$ & $13.3 \%$ & $13.3 \%$ & $6.7 \%$ & $40.0 \%$ & $6.7 \%$ & $0.0 \%$ & $6.7 \%$ & $20.0 \%$ & $0.0 \%$ & $0.0 \%$ & $0.0 \%$ & $6.7 \%$ & $6.7 \%$ & $6.7 \%$ & $6.7 \%$ & $6.7 \%$ & $13.3 \%$ \\
\hline $\mathrm{N} 2$ & $40.0 \%$ & $20.0 \%$ & $26.7 \%$ & $26.7 \%$ & $40.0 \%$ & $40.0 \%$ & $33.3 \%$ & $26.7 \%$ & $6.7 \%$ & $26.7 \%$ & $33.3 \%$ & $20.0 \%$ & $0.0 \%$ & $13.3 \%$ & $33.3 \%$ & $33.3 \%$ & $26.7 \%$ & $26.7 \%$ & $26.7 \%$ & $26.7 \%$ \\
\hline N3 & $26.7 \%$ & $33.3 \%$ & $40.0 \%$ & $33.3 \%$ & $40.0 \%$ & $33.3 \%$ & $20.0 \%$ & $53.3 \%$ & $60.0 \%$ & $46.7 \%$ & $20.0 \%$ & $46.7 \%$ & $66.7 \%$ & $20.0 \%$ & $26.7 \%$ & $20.0 \%$ & $40.0 \%$ & $13.3 \%$ & $20.0 \%$ & $26.7 \%$ \\
\hline N4 & $6.7 \%$ & $40.0 \%$ & $20.0 \%$ & $26.7 \%$ & $6.7 \%$ & $13.3 \%$ & $6.7 \%$ & $13.3 \%$ & $13.3 \%$ & $13.3 \%$ & $6.7 \%$ & $20.0 \%$ & $20.0 \%$ & $33.3 \%$ & $26.7 \%$ & $33.3 \%$ & $26.7 \%$ & $33.3 \%$ & $40.0 \%$ & $13.3 \%$ \\
\hline N5 & $26.7 \%$ & $6.7 \%$ & $6.7 \%$ & $0.0 \%$ & $0.0 \%$ & $6.7 \%$ & $0.0 \%$ & $0.0 \%$ & $20.0 \%$ & $6.7 \%$ & $20.0 \%$ & $13.3 \%$ & $13.3 \%$ & $33.3 \%$ & $6.7 \%$ & $6.7 \%$ & $0.0 \%$ & $20.0 \%$ & $6.7 \%$ & $20.0 \%$ \\
\hline
\end{tabular}

Table 6. Frequency analysis of responses from group E3 (Source: Authors)

\begin{tabular}{|c|c|c|c|c|c|c|c|c|c|c|c|c|c|c|c|c|c|c|c|c|}
\hline Grade & v1 & v2 & v3 & $\mathrm{v4}$ & v5 & v6 & v7 & v8 & v9 & v10 & v11 & v12 & v13 & v14 & v15 & $\mathrm{v16}$ & v17 & v18 & v19 & v20 \\
\hline N1 & $11.1 \%$ & $11.1 \%$ & $0.0 \%$ & $11.1 \%$ & $0.0 \%$ & $0.0 \%$ & $55.6 \%$ & $22.2 \%$ & $0.0 \%$ & $11.1 \%$ & $22.2 \%$ & $\%$ & $11.1 \%$ & $11.1 \%$ & $22.2 \%$ & $22.2 \%$ & $11.1 \%$ & $2.2 \%$ & $33.3 \%$ & $11.1 \%$ \\
\hline $\mathrm{N} 2$ & $55.6 \%$ & $11.1 \%$ & $77.8 \%$ & $66.7 \%$ & $44.4 \%$ & $44.4 \%$ & $44.4 \%$ & $22.2 \%$ & $11.1 \%$ & $44.4 \%$ & $44.4 \%$ & $33.3 \%$ & $33.3 \%$ & $0.0 \%$ & $55.6 \%$ & $44.4 \%$ & $55.6 \%$ & $33.3 \%$ & $44.4 \%$ & $55.6 \%$ \\
\hline N3 & $22.2 \%$ & $66.7 \%$ & $11.1 \%$ & $0.0 \%$ & $55.6 \%$ & $55.6 \%$ & $0.0 \%$ & $44.4 \%$ & $44.4 \%$ & $22.2 \%$ & $33.3 \%$ & $22.2 \%$ & $22.2 \%$ & 03.J & $\%$ & $\%$ & $2 \%$ & $.2 .2 \%$ & $22.2 \%$ & $22.2 \%$ \\
\hline N4 & $11.1 \%$ & $11.1 \%$ & $11.1 \%$ & $22.2 \%$ & $0.0 \%$ & $0.0 \%$ & $0.0 \%$ & $11.1 \%$ & $44.4 \%$ & $22.2 \%$ & $0.0 \%$ & $22.2 \%$ & $33.3 \%$ & $44.4 \%$ & $11.1 \%$ & $0.0 \%$ & $11.1 \%$ & $22.2 \%$ & $0.0 \%$ & $11.1 \%$ \\
\hline N5 & $0.0 \%$ & $0.0 \%$ & $0.0 \%$ & $0.0 \%$ & $0.0 \%$ & $0.0 \%$ & $0.0 \%$ & $0.0 \%$ & $0.0 \%$ & $0.0 \%$ & $0.0 \%$ & $0.0 \%$ & $0.0 \%$ & $11.1 \%$ & $0.0 \%$ & $0.0 \%$ & $0.0 \%$ & $0.0 \%$ & $0.0 \%$ & $0.0 \%$ \\
\hline
\end{tabular}

To perform a comparative analysis of the variables, weighting them via the respondents' experience, the Fuzzy TOPSIS was used, as mentioned. First, each note in Table 3 was replaced by the corresponding fuzzy designation presented in section 3 , which was performed for each of the experience levels E1, E2, and E3. Thus, Score $1=$ $[0 ; 0 ; 0.25]$, Score $2=[0 ; 0.25 ; 0.50]$, Score $3=[0.25 ; 0.5 ; 0.75]$, Score $4=[0.5 ; 0.75 ; 1.00]$, Score $5=[0.75 ; 1.00 ; 1.00], \mathrm{E} 1=[0 ; 0 ; 0.50], \mathrm{E} 2=[0 ; 0.50 ; 1.00], \mathrm{E} 3=[0.50 ; 1.00 ; 1.00]$. For size reasons, the matrices contemplating fuzzy grades and fuzzy experiences are not presented here, since that only the matrix of fuzzy grades presents 34 rows, 20 columns and each fuzzy number consists of 3 parameters.

The matrix with fuzzy grades was normalized and, in the sequence, each of its element were multiplied by respondents' experience (normalized fuzzy responses). After it, it was possible to obtain a matrix V. Once again, due to the matrix size, it is not presented here.

From matrix V and Equation 2, the distances of each element in relation to positive and negative ideal solutions were calculated. The distances for each element were summed, according to equations 3 and 4, which enabled to obtain the total distance in relation to each ideal solution. Vide Tables 7 and 8. 
Table 7. Distances of each element from the positive ideal solution and total distance (di*) represented by the sum of the distances (Source: Authors)

\begin{tabular}{|c|c|c|c|c|c|c|c|c|c|c|c|c|c|c|c|c|c|c|c|c|}
\hline Resp. & v1 & v2 & v3 & $\mathrm{v4}$ & v5 & v6 & v7 & v8 & v9 & v10 & v11 & v12 & v13 & v14 & $\mathrm{v15}$ & v16 & v17 & v18 & v19 & v20 \\
\hline $\mathrm{R} 1$ & 0.96 & 0.89 & 0.89 & 0.92 & 0.96 & 0.92 & 0.96 & 0.92 & 0.87 & 0.92 & 0.92 & 0.92 & 0.87 & 0.87 & 0.92 & 0.92 & 0.92 & 0.96 & 0.92 & 0.89 \\
\hline R2 & 0.89 & 0.87 & 0.87 & 0.87 & 0.87 & 0.87 & 0.92 & 0.92 & 0.89 & 0.89 & 0.92 & 0.92 & 0.92 & 0.87 & 0.87 & 0.87 & 0.87 & 0.89 & 0.89 & 0.87 \\
\hline R3 & 0.90 & 0.90 & 0.90 & 0.90 & 0.90 & 0.87 & 0.90 & 0.90 & 0.90 & 0.90 & 0.87 & 0.90 & 0.90 & 0.90 & 0.90 & 0.90 & 0.90 & 0.90 & 0.90 & 0.90 \\
\hline R4 & 0.87 & 0.92 & 0.87 & 0.87 & 0.87 & 0.87 & 0.92 & 0.87 & 0.87 & 0.87 & 0.92 & 0.87 & 0.87 & 0.87 & 0.87 & 0.87 & 0.87 & 0.87 & 0.87 & 0.87 \\
\hline R5 & 0.89 & 0.92 & 0.96 & 0.92 & 0.96 & 0.92 & 0.96 & 0.96 & 0.92 & 0.92 & 0.89 & 0.89 & 0.92 & 0.87 & 0.92 & 0.89 & 0.92 & 0.96 & 0.92 & 0.96 \\
\hline R6 & 0.89 & 0.92 & 0.92 & 0.89 & 0.92 & 0.92 & 0.92 & 0.92 & 0.89 & 0.89 & 0.89 & 0.92 & 0.89 & 0.87 & 0.92 & 0.89 & 0.92 & 0.92 & 0.89 & 0.89 \\
\hline R7 & 0.92 & 0.92 & 0.89 & 0.92 & 0.89 & 0.89 & 0.92 & 0.92 & 0.89 & 0.87 & 0.89 & 0.92 & 0.92 & 0.89 & 0.92 & 0.92 & 0.92 & 0.92 & 0.89 & 0.92 \\
\hline R8 & 0.89 & 0.89 & 0.92 & 0.92 & 0.89 & 0.92 & 0.92 & 0.92 & 0.92 & 0.92 & 0.89 & 0.92 & 0.92 & 0.92 & 0.87 & 0.89 & 0.92 & 0.89 & 0.89 & 0.89 \\
\hline R9 & 0.87 & 0.89 & 0.87 & 0.87 & 0.89 & 0.89 & 0.92 & 0.89 & 0.89 & 0.89 & 0.87 & 0.87 & 0.87 & 0.87 & 0.89 & 0.89 & 0.89 & 39 & 0.89 & 0.89 \\
\hline R10 & 0.89 & 0.89 & 0.89 & 0.92 & 0.92 & 0.92 & 0.89 & 0.87 & 0.87 & 0.87 & 0.89 & 0.89 & 0.89 & 0.87 & 0.92 & 0.87 & 0.89 & 87 & 0.87 & 0.89 \\
\hline R11 & 0.65 & 0.74 & 0.68 & 0.68 & 0.68 & 0.68 & 0.82 & 0.82 & 0.65 & 0.68 & 0.74 & 0.68 & 0.65 & 0.65 & 0.68 & 0.68 & 0.68 & 0.65 & 0.65 & 0.68 \\
\hline R12 & 0.68 & 0.68 & 0.82 & 0.92 & 0.92 & 0.68 & 0.92 & 0.68 & 0.68 & 0.82 & 0.65 & 0.68 & 0.68 & 0.68 & 0.68 & 0.68 & 0.74 & 68 & 0.68 & 0.68 \\
\hline R13 & 0.82 & 0.74 & 0.82 & 0.74 & 0.74 & 0.82 & 0.92 & 0.82 & 0.68 & 0.82 & 0.92 & 0.74 & 0.68 & 0.68 & 0.82 & 0.82 & 0.74 & 0.82 & 0.82 & 0.82 \\
\hline R14 & 0.82 & 0.68 & 0.74 & 0.82 & 0.82 & 0.82 & 0.82 & 0.74 & 0.74 & 0.92 & 0.92 & 0.82 & 0.74 & 0.82 & 0.82 & 0.82 & 0.82 & 0.68 & 0.68 & 0.74 \\
\hline R15 & 0.78 & 0.69 & 0.69 & 0.69 & 0.69 & 0.69 & 0.78 & 0.78 & 0.69 & 0.69 & 0.78 & 0.78 & 0.69 & 0.69 & 0.69 & 0.78 & 0.69 & 0.78 & 0.78 & 0.78 \\
\hline R16 & 0.74 & 0.82 & 0.92 & 0.92 & 0.92 & 0.82 & 0.92 & 0.74 & 0.74 & 0.74 & 0.82 & 0.74 & 0.74 & 0.68 & 0.92 & 0.82 & 0.92 & 0.92 & 0.92 & 0.92 \\
\hline R17 & 0.74 & 0.74 & 0.74 & 0.82 & 0.82 & 0.82 & 0.82 & 0.74 & 0.74 & 0.68 & 0.82 & 0.74 & 0.74 & 0.65 & 0.74 & 0.74 & 0.74 & 0.74 & 0.74 & 0.74 \\
\hline R18 & 0.74 & 0.68 & 0.74 & 0.68 & 0.74 & 0.74 & 0.74 & 0.68 & 0.74 & 0.74 & 0.74 & 0.74 & 0.74 & 0.68 & 0.68 & 0.68 & 0.68 & 0.68 & 0.68 & 0.74 \\
\hline R19 & 0.65 & 0.68 & 0.68 & 0.68 & 0.82 & 0.82 & 0.74 & 0.74 & 0.74 & 0.74 & 0.65 & 0.65 & 0.65 & 0.65 & 0.68 & 0.68 & 0.68 & 0.65 & 0.68 & 0.65 \\
\hline R20 & 0.74 & 0.68 & 0.74 & 0.74 & 0.82 & 0.74 & 0.82 & 0.74 & 0.74 & 0.74 & 0.82 & 0.74 & 0.74 & 0.68 & 0.82 & 0.74 & 0.82 & 0.68 & 0.68 & 0.74 \\
\hline R21 & 0.65 & 0.68 & 0.68 & 0.68 & 0.74 & 0.82 & 0.92 & 0.74 & 0.65 & 0.74 & 0.68 & 0.68 & 0.68 & 0.65 & 0.74 & 0.68 & 0.74 & 0.68 & 0.74 & 0.65 \\
\hline R22 & 0.82 & 0.74 & 0.74 & 0.82 & 0.82 & 0.74 & 0.68 & 0.74 & 0.74 & 0.74 & 0.74 & 0.74 & 0.74 & 0.74 & 0.74 & 0.74 & 0.82 & 0.82 & 0.82 & 0.82 \\
\hline R23 & 0.78 & 0.78 & 0.78 & 0.78 & 0.78 & 0.90 & 0.90 & 0.90 & 0.69 & 0.78 & 0.78 & 0.69 & 0.69 & 0.69 & 0.78 & 0.90 & 0.78 & 0.78 & 0.78 & 0.78 \\
\hline R24 & 0.65 & 0.65 & 0.65 & 0.74 & 0.74 & 0.65 & 0.74 & 0.74 & 0.65 & 0.65 & 0.65 & 0.65 & 0.74 & 0.65 & 0.65 & 0.65 & 0.74 & 0.65 & 0.74 & 0.65 \\
\hline R25 & 0.82 & 0.82 & 0.82 & 0.74 & 0.74 & 0.74 & 0.92 & 0.82 & 0.82 & 0.82 & 0.92 & 0.82 & 0.74 & 0.82 & 0.82 & 0.82 & 0.68 & 0.74 & 0.68 & 0.92 \\
\hline R26 & & 0.46 & 0.78 & 0.92 & 0.78 & & 0.92 & & & & & & & 0.46 & & 0.78 & 0.60 & 0 & 0.78 & 0.60 \\
\hline R27 & 0.46 & 0.60 & 0.78 & 0.78 & 0.78 & 0.78 & 0.78 & 0.60 & 0.46 & 0.46 & 0.60 & 0.46 & 0.46 & 0.36 & 0.46 & 0.60 & 0.46 & 0.46 & 0.60 & 0.78 \\
\hline R28 & 0.72 & 0.90 & 0.72 & 0.72 & 0.72 & 0.72 & 0.90 & 0.72 & 0.72 & 0.72 & 0.72 & 0.90 & 0.72 & 0.52 & 0.90 & 0.72 & 0.72 & 0.90 & 0.90 & 0.72 \\
\hline R29 & 0.60 & 0.60 & 0.78 & 0.78 & 0.60 & 0.60 & 0.78 & 0.60 & 0.46 & 0.46 & 0.78 & 0.60 & 0.46 & 0.46 & 0.78 & 0.78 & 0.78 & 0.78 & 0.78 & 0.78 \\
\hline R30 & 0.72 & 0.72 & 0.72 & 0.72 & 0.72 & 0.52 & 0.72 & 0.52 & 0.52 & 0.72 & 0.72 & 0.72 & 0.72 & 0.52 & 0.90 & 0.90 & 0.72 & 0.72 & 0.72 & 0.72 \\
\hline R31 & 0.92 & 0.60 & 0.78 & 0.46 & 0.60 & 0.60 & 0.92 & 0.92 & 0.60 & 0.92 & 0.92 & 0.92 & 0.92 & 0.92 & 0.78 & 0.92 & 0.92 & 0.46 & 0.92 & 0.46 \\
\hline R32 & 0.60 & 0.60 & 0.46 & 0.46 & 0.60 & 0.60 & 0.78 & 0.60 & 0.60 & 0.60 & 0.60 & 0.78 & 0.78 & 0.60 & 0.60 & 0.60 & 0.60 & 0.60 & 0.60 & 0.60 \\
\hline R33 & 0.78 & 0.60 & 0.60 & 0.78 & 0.60 & 0.78 & 0.92 & 0.92 & 0.60 & 0.78 & 0.78 & 0.46 & 0.46 & 0.46 & 0.78 & 0.78 & 0.78 & 0.92 & 0.92 & 0.92 \\
\hline R34 & 0.78 & 0.60 & 0.78 & 0.78 & 0.60 & 0.60 & 0.92 & 0.46 & 0.46 & 0.60 & 0.60 & 0.60 & 0.60 & 0.46 & 0.78 & 0.60 & 0.78 & 0.78 & 0.78 & 0.78 \\
\hline Sum & 26.37 & 25.50 & 26.59 & 26.85 & 26.85 & 26.44 & 29.38 & 26.61 & 24.44 & 26.26 & 27.22 & 26.11 & 25.30 & 23.92 & 27.01 & 26.81 & 26.65 & 26.22 & 27.00 & 26.62 \\
\hline
\end{tabular}

Table 8. Distances of each element from the negative ideal solution and total distance (di') represented by the sum of distances (Source: Authors)

\begin{tabular}{|c|c|c|c|c|c|c|c|c|c|c|c|c|c|c|c|c|c|c|c|c|}
\hline Resp. & v1 & v2 & v3 & v4 & v5 & v6 & v7 & v8 & v9 & v10 & v11 & v12 & v13 & v14 & v15 & v16 & v17 & v18 & v19 & v20 \\
\hline $\mathrm{R} 1$ & 0.07 & 0.22 & 0.22 & 0.14 & 0.07 & 0.14 & 0.07 & 0.14 & 0.29 & 0.14 & 0.14 & 0.14 & 0.29 & 0.29 & 0.14 & 0.14 & 0.14 & 0.07 & 0.14 & 0.22 \\
\hline $\mathrm{R} 2$ & 0.22 & 0.29 & 0.29 & 0.29 & 0.29 & 0.29 & 0.14 & 0.14 & 0.22 & 0.22 & 0.14 & 0.14 & 0.14 & 0.29 & 0.29 & 0.29 & 0.29 & 0.22 & 0.22 & 0.29 \\
\hline R3 & 0.19 & 0.19 & 0.19 & 0.19 & 0.19 & 0.29 & 0.19 & 0.19 & 0.19 & 0.19 & 0.29 & 0.19 & 0.19 & 0.19 & 0.19 & 0.19 & 0.19 & 0.19 & 0.19 & 0.19 \\
\hline $\mathrm{R} 4$ & 0.29 & 0.14 & 0.29 & 0.29 & 0.29 & 0.29 & 0.14 & 0.29 & 0.29 & 0.29 & 0.14 & 0.29 & 0.29 & 0.29 & 0.29 & 0.29 & 0.29 & 0.29 & 0.29 & 0.29 \\
\hline R5 & 0.22 & 0.14 & 0.07 & 0.14 & 0.07 & 0.14 & 0.07 & 0.07 & 0.14 & 0.14 & 0.22 & 0.22 & 0.14 & 0.29 & 0.14 & 0.22 & 0.14 & 0.07 & 0.14 & 0.07 \\
\hline R6 & 0.22 & 0.14 & 0.14 & 0.22 & 0.14 & 0.14 & 0.14 & 0.14 & 0.22 & 0.22 & 0.22 & 0.14 & 0.22 & 0.29 & 0.14 & 0.22 & 0.14 & 0.14 & 0.22 & 0.22 \\
\hline R7 & 0.14 & 0.14 & 0.22 & 0.14 & 0.22 & 0.22 & 0.14 & 0.14 & 0.22 & 0.29 & 0.22 & 0.14 & 0.14 & 0.22 & 0.14 & 0.14 & 0.14 & 0.14 & 0.22 & 0.14 \\
\hline R8 & 0.22 & 0.22 & 0.14 & 0.14 & 0.22 & 0.14 & 0.14 & 0.14 & 0.14 & 0.14 & 0.22 & 0.14 & 0.14 & 0.14 & 0.29 & 0.22 & 0.14 & 0.22 & 0.22 & 0.22 \\
\hline R9 & 0.29 & 0.22 & 0.29 & 0.29 & 0.22 & 0.22 & 0.14 & 0.22 & 0.22 & 0.22 & 0.29 & 0.29 & 0.29 & 0.29 & 0.22 & 0.22 & 0.22 & 0.22 & 0.22 & 0.22 \\
\hline $\mathrm{R} 10$ & 0.22 & 0.22 & 0.22 & 0.14 & 0.14 & 0.14 & 0.22 & 0.29 & 0.29 & 0.29 & 0.22 & 0.22 & 0.22 & 0.29 & 0.14 & 0.29 & 0.22 & 0.29 & 0.29 & 0.22 \\
\hline R11 & 0.65 & 0.46 & 0.62 & 0.62 & 0.62 & 0.62 & 0.30 & 0.30 & 0.65 & 0.62 & 0.46 & 0.62 & 0.65 & 0.65 & 0.62 & 0.62 & 0.62 & 0.65 & 0.65 & 0.62 \\
\hline $\mathrm{R} 12$ & 0.62 & 0.62 & 0.30 & 0.14 & 0.14 & 0.62 & 0.14 & 0.61 & 0.62 & 0.30 & 0.65 & 0.62 & 0.62 & 0.62 & 0.62 & 0.62 & 0.46 & 0.62 & 0.62 & 0.62 \\
\hline $\mathrm{R} 13$ & 0.30 & 0.46 & 0.30 & 0.46 & 0.46 & 0.30 & 0.14 & 0.30 & 0.62 & 0.30 & 0.14 & 0.46 & 0.62 & 0.62 & 0.30 & 0.30 & 0.46 & 0.30 & 0.30 & 0.30 \\
\hline R14 & 0.30 & 0.62 & 0.46 & 0.30 & 0.30 & 0.30 & 0.30 & 0.45 & 0.46 & 0.14 & 0.14 & 0.30 & 0.46 & 0.30 & 0.30 & 0.30 & 0.30 & 0.62 & 0.62 & 0.46 \\
\hline R15 & 0.40 & 0.61 & 0.61 & 0.61 & 0.61 & 0.61 & 0.40 & 0.39 & 0.61 & 0.61 & 0.40 & 0.40 & 0.61 & 0.61 & 0.61 & 0.40 & 0.61 & 0.40 & 0.40 & 0.40 \\
\hline R16 & 0.46 & 0.30 & 0.14 & 0.14 & 0.14 & 0.30 & 0.14 & 0.45 & 0.46 & 0.46 & 0.30 & 0.46 & 0.46 & 0.62 & 0.14 & 0.30 & 0.14 & 0.14 & 0.14 & 0.14 \\
\hline R17 & 0.46 & 0.46 & 0.46 & 0.30 & 0.30 & 0.30 & 0.30 & 0.45 & 0.46 & 0.62 & 0.30 & 0.46 & 0.46 & 0.65 & 0.46 & 0.46 & 0.46 & 0.46 & 0.46 & 0.46 \\
\hline $\mathrm{R} 18$ & 0.46 & 0.62 & 0.46 & 0.62 & 0.46 & 0.46 & 0.46 & 0.61 & 0.46 & 0.46 & 0.46 & 0.46 & 0.46 & 0.62 & 0.62 & 0.62 & 0.62 & 0.62 & 0.62 & 0.46 \\
\hline R19 & 0.65 & 0.62 & 0.62 & 0.62 & 0.30 & 0.30 & 0.46 & 0.45 & 0.46 & 0.46 & 0.65 & 0.65 & 0.65 & 0.65 & 0.62 & 0.62 & 0.62 & 0.65 & 0.62 & 0.65 \\
\hline R20 & 0.46 & 0.62 & 0.46 & 0.46 & 0.30 & 0.46 & 0.30 & 0.45 & 0.46 & 0.46 & 0.30 & 0.46 & 0.46 & 0.62 & 0.30 & 0.46 & 0.30 & 0.62 & 0.62 & 0.46 \\
\hline $\mathrm{R} 21$ & 0.65 & 0.62 & 0.62 & 0.62 & 0.46 & 0.30 & 0.14 & 0.45 & 0.65 & 0.46 & 0.62 & 0.62 & 0.62 & 0.65 & 0.46 & 0.62 & 0.46 & 0.62 & 0.46 & 0.65 \\
\hline R22 & 0.30 & 0.46 & 0.46 & 0.30 & 0.30 & 0.46 & 0.62 & 0.45 & 0.46 & 0.46 & 0.46 & 0.46 & 0.46 & 0.46 & 0.46 & 0.46 & 0.30 & 0.30 & 0.30 & 0.30 \\
\hline $\mathrm{R} 23$ & 0.40 & 0.40 & 0.40 & 0.40 & 0.40 & 0.19 & 0.19 & 0.19 & 0.61 & 0.40 & 0.40 & 0.61 & 0.61 & 0.61 & 0.40 & 0.19 & 0.40 & 0.40 & 0.40 & 0.40 \\
\hline $\mathrm{R} 24$ & 0.65 & 0.65 & 0.65 & 0.46 & 0.46 & 0.65 & 0.46 & 0.45 & 0.65 & 0.65 & 0.65 & 0.65 & 0.46 & 0.65 & 0.65 & 0.65 & 0.46 & 0.65 & 0.46 & 0.65 \\
\hline
\end{tabular}




\begin{tabular}{|c|c|c|c|c|c|c|c|c|c|c|c|c|c|c|c|c|c|c|c|c|}
\hline R25 & 0.30 & 0.30 & 0.30 & 0.46 & 0.46 & 0.46 & 0.14 & 0.30 & 0.30 & 0.30 & 0.14 & 0.30 & 0.46 & 0.30 & 0.30 & 0.30 & 0.62 & 0.46 & 0.62 & 0.14 \\
\hline R26 & 0.32 & 0.74 & 0.32 & 0.14 & 0.32 & 0.32 & 0.14 & 0.32 & 0.74 & 0.32 & 0.14 & 0.32 & 0.53 & 0.74 & 0.32 & 0.32 & 0.53 & 0.53 & 0.32 & 0.53 \\
\hline $\mathrm{R} 27$ & 0.74 & 0.53 & 0.32 & 0.32 & 0.32 & 0.32 & 0.32 & 0.52 & 0.74 & 0.74 & 0.53 & 0.74 & 0.74 & 0.84 & 0.74 & 0.53 & 0.74 & 0.74 & 0.53 & 0.32 \\
\hline $\mathrm{R} 28$ & 0.43 & 0.19 & 0.43 & 0.43 & 0.43 & 0.43 & 0.19 & 0.43 & 0.43 & 0.43 & 0.43 & 0.19 & 0.43 & 0.70 & 0.19 & 0.43 & 0.43 & 0.19 & 0.19 & 0.43 \\
\hline R29 & 0.53 & 0.53 & 0.32 & 0.32 & 0.53 & 0.53 & 0.32 & 0.52 & 0.74 & 0.74 & 0.32 & 0.53 & 0.74 & 0.74 & 0.32 & 0.32 & 0.32 & 0.32 & 0.32 & 0.32 \\
\hline $\mathrm{R} 30$ & 0.43 & 0.43 & 0.43 & 0.43 & 0.43 & 0.70 & 0.43 & 0.70 & 0.70 & 0.43 & 0.43 & 0.43 & 0.43 & 0.70 & 0.19 & 0.19 & 0.43 & 0.43 & 0.43 & 0.43 \\
\hline R31 & 0.14 & 0.53 & 0.32 & 0.74 & 0.53 & 0.53 & 0.14 & 0.14 & 0.53 & 0.14 & 0.14 & 0.14 & 0.14 & 0.14 & 0.32 & 0.14 & 0.14 & 0.74 & 0.14 & 0.74 \\
\hline R32 & 0.53 & 0.53 & 0.74 & 0.74 & 0.53 & 0.53 & 0.32 & 0.52 & 0.53 & 0.53 & 0.53 & 0.32 & 0.32 & 0.53 & 0.53 & 0.53 & 0.53 & 0.53 & 0.53 & 0.53 \\
\hline R33 & 0.32 & 0.53 & 0.53 & 0.32 & 0.53 & 0.32 & 0.14 & 0.14 & 0.53 & 0.32 & 0.32 & 0.74 & 0.74 & 0.74 & 0.32 & 0.32 & 0.32 & 0.14 & 0.14 & 0.14 \\
\hline R34 & 0.32 & 0.53 & 0.32 & 0.32 & 0.53 & 0.53 & 0.14 & 0.73 & 0.74 & 0.53 & 0.53 & 0.53 & 0.53 & 0.74 & 0.32 & 0.53 & 0.32 & 0.32 & 0.32 & 0.32 \\
\hline Sum & 12.84 & 14.21 & 12.62 & 12.24 & 11.67 & 12.51 & 8.07 & 12.14 & 15.74 & 12.97 & 11.51 & 13.34 & 14.66 & 17.01 & 12.08 & 12.40 & 12.48 & 13.25 & 12.32 & 12.50 \\
\hline
\end{tabular}

Knowing the values of $\mathrm{di}^{*}$ and $\mathrm{di}_{\mathrm{i}}^{-}$for each variable, it was possible to calculate the closeness coeficients $\left(\mathrm{CC}_{\mathrm{i}}\right)$ through equation 5 , as presented in Table 9.

Table 9. Closeness Coefficient $\left(\mathrm{CC}_{\mathrm{i}}\right)$ calculated from the values of $\mathrm{d}_{\mathrm{i}}{ }^{*}$ and $\mathrm{d}_{\mathrm{i}}{ }^{-}$(Source: Authors)

\begin{tabular}{cccc|c|ccc}
\hline var & $\mathrm{d}_{\mathrm{i}}{ }^{*}$ & $\mathrm{~d}_{\mathrm{i}}{ }^{-}$ & $\mathrm{CCi}$ & $\mathrm{var}$ & $\mathrm{d}_{\mathrm{i}}{ }^{*}$ & $\mathrm{~d}_{\mathrm{i}}{ }^{-}$ & $\mathrm{CCi}$ \\
\hline $\mathrm{v} 1$ & 26.37 & 12.84 & 0.32741 & $\mathrm{v} 11$ & 27.22 & 11.51 & 0.29712 \\
$\mathrm{v} 2$ & 25.50 & 14.21 & 0.35783 & $\mathrm{v} 12$ & 26.11 & 13.34 & 0.33812 \\
$\mathrm{v} 3$ & 26.59 & 12.62 & 0.32193 & $\mathrm{v} 13$ & 25.30 & 14.66 & 0.36692 \\
v4 & 26.85 & 12.24 & 0.31322 & $\mathrm{v} 14$ & 23.92 & 17.01 & 0.41559 \\
v5 & 26.85 & 11.67 & 0.30288 & $\mathrm{v} 15$ & 27.01 & 12.08 & 0.30898 \\
v6 & 26.44 & 12.51 & 0.32123 & $\mathrm{v} 16$ & 26.81 & 12.40 & 0.31627 \\
v7 & 29.38 & 8.07 & 0.21559 & $\mathrm{v} 17$ & 26.65 & 12.48 & 0.31887 \\
v8 & 26.61 & 12.14 & 0.31434 & $\mathrm{v} 18$ & 26.22 & 13.25 & 0.33573 \\
v9 & 24.44 & 15.74 & 0.39179 & $\mathrm{v} 19$ & 27.00 & 12.32 & 0.31329 \\
$\mathrm{v} 10$ & 26.26 & 12.97 & 0.33070 & $\mathrm{v} 20$ & 26.62 & 12.50 & 0.31959 \\
\hline
\end{tabular}

Finally, the closeness coefficients $\left(\mathrm{CC}_{\mathrm{i}}\right)$ were used to rank the variables according to responses intensity. Table 10 presents the variables (topics) ranked according to $\mathrm{CC}_{\mathrm{i}}$ values 
Table 10. Topics ranked by the values of $\mathrm{CC}_{\mathrm{i}}$ (Source: Authors)

\begin{tabular}{cccl}
\hline$\#$ & var & CCi. & \\
\hline $1^{\circ}$ & v14 & 0.41559 & Quality Management Systems and related standards (e.g. ISO 9001) \\
$2^{\text {o }}$ & v9 & 0.39179 & Environmental Management Systems and other related standards (e.g. ISO 14001; ISO 14020; ISO 14040) \\
$3^{\text {o }}$ & v13 & 0.36692 & Compliance with environmental laws, regulations and standards \\
$4^{\circ}$ & v2 & 0.35783 & Preventing use, reuse, collection, separation, recovery, and proper disposal of materials. \\
$5^{\circ}$ & v12 & 0.33812 & Compliance with laws, regulations and social standards \\
$6^{\circ}$ & v18 & 0.33573 & Inserting sustainability into long term strategies \\
$7^{\circ}$ & v10 & 0.33070 & Occupational health and safety management systems and other standards (e.g. OSHAS 18001; ISO 45001) \\
$8^{\circ}$ & v1 & 0.32741 & Definition and assessment of all stakeholder requirements \\
$9^{\circ}$ & v3 & 0.32193 & Use of renewable materials \\
$10^{\circ}$ & v6 & 0.32123 & Energy efficient production \\
$11^{\circ}$ & v20 & 0.31959 & Assessment of environmental and social performance of suppliers \\
$12^{\circ}$ & v17 & 0.31887 & Use of energy from renewable sources \\
$13^{\circ}$ & v16 & 0.31627 & Top management involvement in the pursuit of sustainable development \\
$14^{\circ}$ & v8 & 0.31434 & Standards related to corporate social responsibility (e.g. ISO 16001; SA 8000 and ISO 26000) \\
$15^{\circ}$ & v19 & 0.31329 & Research and Development for Sustainability \\
$16^{\circ}$ & v4 & 0.31322 & Reduction and prevention of greenhouse gas emissions / carbon footprint \\
$17^{\circ}$ & v15 & 0.30898 & Guidelines for the efficient use and reuse of water \\
$18^{\circ}$ & v5 & 0.30288 & Energy efficient products and services and promotion of initiatives to reduce indirect energy consumption \\
$19^{\circ}$ & v11 & 0.29712 & Worker training \\
$20^{\circ}$ & v7 & 0.21559 & Knowledge governance practices for combating corruption and bribes \\
\hline & & &
\end{tabular}

\section{Debates}

Once presented the results obtained, it is possible to discuss them in the light of the literature. Through Tables 4, 5 and 6, it can be observed predominant frequencies for the three groups in the grades 2 and 3, which generally indicate that the topics are covered within other subjects, superficially or with a higher attention. These finding is in agreement with Leal Filho et al. (2019) and Rampasso (2018) which show that, in general, concepts about sustainability are poorly debated in higher education and their insertion faces considerable barriers.

For a few topics, the most relevant frequencies of answers in score 4 (topics fully theoretical) and practically zero or non-relevant frequencies in score 5 are observed, indicating that theory and practice are still poorly integrated in the teaching of the topics studied (as it was indicated in the scale provided for respondents to evaluate the item). In this sense, Sharma et al. (2017) argue about the lack of practical activities associated with the theoretical concepts of sustainability, characterizing this scenario as a challenge to be overcome in the institutions. When comparing respondents' groups, it can be noted that group 3 is generally more critical, demonstrating that more experienced professors identify a greater need for improvement in teaching associated with sustainable development. 
Comparative analysis via Fuzzy TOPSIS demonstrated that four key topics are highlighted. These topics are related to ISO standards (related to quality and environmental management systems) and compliance with environmental laws, regulations and standards. It is logical that, as emphasized by Arribas Díaz and MartínezMediano (2018), ISO standards and laws are characterized as important teaching tools, however they correspond broadly to the final results of intense debates promoted by society. Engineering students need to be continually involved in discussions of all levels about sustainable development and not only have contact with these "final results". For this, pedagogical methods such as problem-based learning, service learning and community based learning can be used, as pointed out by Guerra (2017).

The last positions of the ranking obtained via Fuzzy TOPSIS are occupied by three themes considered extremely important in the formation of future engineers. The energy issue is becoming increasingly central in the business context (Javied et al., 2015). However, the number of studies addressing energy efficiency in products use is still scarce (Li et al., 2019). Specifically for learning objectives of SDG 7 (“Affordable and clean energy"), UNESCO (2017) emphasize the need "to apply and evaluate measures in order to increase energy efficiency and sufficiency in their personal sphere and to increase the share of renewable energy in their local energy mix" (p. 24). According to the respondents, this theme is still poorly inserted in the engineering courses offered in Brazil. This objective is directly related to engineers tasks for product design. In this sense, the lack of a proper training of engineering students to consider energy efficiency needs during a new product development can be consider as a barrier to reach SDG 7.

The item related to worker training is also an important role that engineers can play towards sustainable development. More specifically, it can be linked to SDG 8 ("Decent Work and Economic Growth") (UN, 2015), since worker training can improve the quality of jobs (Cooke et al., 2019). UNESCO (2017) emphasize that students need to be taught about the importance of aligning economic growth with decent work opportunities. In this sense, the authors of this article argue that engineering students need to learn better about their future role as engineers to act towards workers training. In addition, it should be highlighted that in Rampasso, Anholon, Silva, Cooper Ordoñez, et al. (2019) study, it is verified that the analyzed sample of engineering students do not considered employees and local community issues as items related to sustainability analysis, which corroborates with the findings of this research. 
The item ranked in last position was "Knowledge governance practices for combating corruption and bribes". It is related to SDG 16 "Peace, Justice and Strong Institutions" (UN, 2015). Jacoby et al. (2019) highlight the importance of considering and discussing aspects of corporate governance for the development of emerging economies. Focusing on ethical education, Monteiro et al. (2019) emphasize the importance of it in engineering education, training students to include ethical judgements in their professional decisions. In this sense, the authors of this article argue that engineering students need to be prepared for dealing with situations related to ethical issues, such as corruption and bribes, not only to not get involved in this type of infraction, but to understand the seriousness of these actions and how they can act to combat this when they are in the job market.

Finally, considering the debates presented above, it can be highlighted that, from a theoretical perspective, this study contributes to the literature exploring ways to measure the insertion of sustainability in engineering education, as well as developing roadmaps and guidelines for methods to better prepare engineering students to work towards sustainable development. From a practical perspective, professors and coordinators can use these findings to improve the way they insert sustainability into engineering education, since Brazilian HEIs still have a long path to be crossed. In addition, they can use an assessment similar to the one presented to verify the main focus of attention in their HEIs.

\section{Conclusions and final considerations}

This article aimed to critically analyze the engineering education focused on sustainable supply chain management, in courses offered by Brazilian HEIs. From the results presented, it can be stated that the objective was achieved. Taking the study of Fritz et al. (2017) as a basis, 20 topics related to supply chain sustainable management were established and evaluated by 34 professors experienced in this field and that know the reality of Brazilian HEIs.

Data evaluation was performed via frequency analysis and comparative ordering of the topics was studied via the Fuzzy TOPSIS technique, as proposed by Chen (2000). It was possible to evidence that most of the topics in general are superficially addressed within other subjects, thus having ample possibilities for greater detail and association of these topics with practical activities that enable greater learning. When comparing the 
topics, those related to ISO standard (related to quality and environmental management systems) and compliance with environmental laws, regulations and standards were highlighted. It is clear the need for greater insertion of sustainability in the disciplines associated with supply chain management.

In view of the results and debates presented, the theoretical and practical implications can be highlighted. The theoretical point of view, the findings presented here can contribute with researchers to better explore ways to measure sustainability insertion in engineering education. From a practical point of view, professors and coordinators can use these findings to improve the manner they insert sustainability in engineering education. Additionally, they can perform similar evaluation as the one presented in this article to verify the main attention focus in their HEIs. The present work has an exploratory character and can greatly contribute to broaden the debates related to new forms of engineering education and the insertion of sustainability.

The main limitation of the research is characterized by the size of the sample; however, it is noteworthy that the participants are professors who have good knowledge about the engineering education in Brazilian reality. Future research may propose to carry out similar surveys but focused on specific engineering modalities and later comparison of results. In addition, applying the survey with students can be useful to identify the perception of them about the same issues. Also, the results presented here can be used in the structuring of an action plan to be validated through an action research in the context of engineering education. In addition, other areas of higher education should also be analyzed in future research to further promote the expansion of debates in this context.

\section{References}

Ahi, P. and Searcy, C. (2013), “A comparative literature analysis of definitions for green and sustainable supply chain management", Journal of Cleaner Production, Elsevier Ltd, Vol. 52, pp. 329-341.

Akram, M., Shumaiza and Arshad, M. (2020), "Bipolar fuzzy TOPSIS and bipolar fuzzy ELECTRE-I methods to diagnosis", Computational and Applied Mathematics, Springer International Publishing, Vol. 39 No. 1, available at:https://doi.org/10.1007/s40314-019-0980-8.

Aleixo, A.M., Azeiteiro, U. and Leal, S. (2018), “The implementation of sustainability 
practices in Portuguese higher education institutions", International Journal of Sustainability in Higher Education, Vol. 19 No. 1, pp. 146-178.

Anastasiadis, S., Perkiss, S., Dean, B.A., Bayerlein, L., Gonzalez-Perez, M.A., Wersun, A., Acosta, P., et al. (2020), "Teaching sustainability: complexity and compromises", Journal of Applied Research in Higher Education, available at:https://doi.org/10.1108/JARHE-02-2020-0029.

Arribas Díaz, J.A. and Martínez-Mediano, C. (2018), “The impact of ISO quality management systems on primary and secondary schools in Spain", Quality Assurance in Education, Vol. 26 No. 1, pp. 2-24.

Avelar, A.B.A., Silva-Oliveira, K.D. da and Pereira, R. da S. (2019), "Education for advancing the implementation of the Sustainable Development Goals: A systematic approach", International Journal of Management Education, Elsevier, Vol. 17 No. 3, p. 100322 .

Bai, C., Sarkis, J., Yin, F. and Dou, Y. (2019), "Sustainable supply chain flexibility and its relationship to circular economy-target performance", International Journal of Production Research, Taylor \& Francis, Vol. 0 No. 0, pp. 1-18.

Ballou, R.H. (2004), Business Logistics/Supply Chain Management: Planning, Organizing and Controlling the Supply Chain, 5th Editio., Pearson/Prentice Hall Inc., New Jersey.

Bradley, P., Parry, G. and O’Regan, N. (2020), “A framework to explore the functioning and sustainability of business models", Sustainable Production and Consumption, Elsevier B.V., Vol. 21, pp. 57-77.

Brazil. (2019), "Resolution $\mathrm{n}^{\circ} 2$ of April 24, 2019. Institutes the National Curriculum Guidelines of Engineering Undergraduate Course", available at: http://portal.mec.gov.br/index.php?option $=$ com_docman\&view $=$ download\&alias $=$ 112681-rces002-19\&category_slug=abril-2019-pdf\&Itemid=30192 (accessed 20 July 2019).

Chen, C.-T. (2000), "Extensions of the TOPSIS for group decision-making under fuzzy environment”, Fuzzy Sets and Systems, Vol. 114 No. 1, pp. 1-9.

Chiappetta Jabbour, C.J., Fiorini, P.D.C., Ndubisi, N.O., Queiroz, M.M. and Piato, É.L. (2020), "Digitally-enabled sustainable supply chains in the 21 st century: A review and a research agenda", Science of the Total Environment, Elsevier B.V., Vol. 725, 


\section{p. 138177.}

Cooke, F.L., Xu, J. and Bian, H. (2019), “The prospect of decent work, decent industrial relations and decent social relations in China: towards a multi-level and multidisciplinary approach", International Journal of Human Resource Management, Vol. 30 No. 1, pp. 122-155.

Corrêa, M., Lima, B.V. de M., Martins, V.W.B., Rampasso, I.S., Anholon, R., Quelhas, O.L.G. and Leal Filho, W. (2020), "An analysis of the insertion of sustainability elements in undergraduate design courses offered by Brazilian higher education institutions: An exploratory study", Journal of Cleaner Production, Vol. 272, available at:https://doi.org/10.1016/j.jclepro.2020.122733.

D’Amato, D., Korhonen, J. and Toppinen, A. (2019), "Circular, Green, and Bio Economy: How Do Companies in Land-Use Intensive Sectors Align with Sustainability Concepts?", Ecological Economics, Elsevier, Vol. 158 No. April 2018, pp. 116-133.

Doni, F., Corvino, A. and Bianchi Martini, S. (2019), "Servitization and sustainability actions. Evidence from European manufacturing companies", Journal of Environmental Management, Elsevier, Vol. 234 No. January, pp. 367-378.

Doukas, H. and Nikas, A. (2020), "Decision support models in climate policy", European Journal of Operational Research, Elsevier B.V., Vol. 280 No. 1, pp. 1-24.

Dubey, R., Gunasekaran, A., Childe, S.J., Papadopoulos, T. and Fosso Wamba, S. (2017), "World class sustainable supply chain management: critical review and further research directions", The International Journal of Logistics Management, Vol. 28 No. 2, pp. 332-362.

Elkington, J. (1997), Cannibals with Forks: The Triple Bottom Line of 21st Century Business, Capstone, Oxford.

Felgueiras, M.C., Rocha, J.S. and Caetano, N. (2017), "Engineering education towards sustainability”, Energy Procedia, Elsevier B.V., Vol. 136, pp. 414-417.

Figueiró, P.S. and Raufflet, E. (2015), "Sustainability in higher education: A systematic review with focus on management education", Journal of Cleaner Production, Vol. 106, pp. 22-33.

Fritz, M.M.C. (2019), “Sustainable Supply Chain Management”, in W. Leal Filho et al. 
(eds.) (Ed.), Responsible Consumption and Production, Encyclopedia of the UN Sustainable Development Goals, Springer, Cham, pp. 1-14.

Fritz, M.M.C., Schöggl, J.-P. and Baumgartner, R.J. (2017), "Selected sustainability aspects for supply chain data exchange: Towards a supply chain-wide sustainability assessment", Journal of Cleaner Production, Vol. 141, pp. 587-607.

Guerra, A. (2017), “Integration of sustainability in engineering education”, International Journal of Sustainability in Higher Education, Vol. 18 No. 3, pp. 436-454.

Jabbour, C.J.C., Jabbour, A.B.L. de S., Leal Filho, W. and Gunasekaran, A. (2015), “The Millennium Development Goals and Production Engineering training”, Industrial and Commercial Training, Vol. 47 No. 6, pp. 293-301.

Jacoby, G., Liu, M., Wang, Y., Wu, Z. and Zhang, Y. (2019), "Corporate governance, external control, and environmental information transparency: Evidence from emerging markets", Journal of International Financial Markets, Institutions and Money, Elsevier B.V., Vol. 58, pp. 269-283.

Jalilian, N. and Mirghafoori, S.H. (2020), "Presenting sustainable supply chain fuzzy rotation matrix framework to manage business challenges in the context of sustainable supply chain management", Journal of Modelling in Management, Vol. 15 No. 1, pp. 35-49.

Javied, T., Rackow, T. and Franke, J. (2015), "Implementing Energy Management System to Increase Energy Efficiency in Manufacturing Companies", Procedia CIRP, Elsevier B.V., Vol. 26, pp. 156-161.

José Sá, M. (2020), “'The secret to success'. Becoming a successful student in a fastchanging higher education environment", European Journal of Higher Education, Taylor \& Francis, Vol. 0 No. 0, pp. 1-16.

Khan, S.A.R. and Qianli, D. (2017), "Impact of green supply chain management practices on firms' performance: an empirical study from the perspective of Pakistan", Environmental Science and Pollution Research, Environmental Science and Pollution Research, Vol. 24 No. 20, pp. 16829-16844.

Leal Filho, W., Skanavis, C., Kounani, A., Brandli, L.L., Shiel, C., Paço, A. do, Pace, P., et al. (2019), "The role of planning in implementing sustainable development in a higher education context”, Journal of Cleaner Production, Elsevier Ltd, Vol. 235, pp. 678-687. 
Li, L., Yu, S. and Tao, J. (2019), "Design for energy efficiency in early stages: A topdown method for new product development", Journal of Cleaner Production, Vol. 224, pp. 175-187.

Martins, V., Anholon, R., Quelhas, O.L.G. and Filho, W. (2019), "Sustainable Practices in Logistics Systems: An Overview of Companies in Brazil”, Sustainability, Vol. 11 No. 15 , p. 4140.

Martins, V.W.B., Rampasso, I.S., Anholon, R., Quelhas, O.L.G. and Leal Filho, W. (2019), "Knowledge management in the context of sustainability: Literature review and opportunities for future research", Journal of Cleaner Production, Elsevier Ltd, Vol. 229, pp. 489-500.

Monteiro, F., Leite, C. and Rocha, C. (2019), "Ethical education as a pillar of the future role of higher education: Analysing its presence in the curricula of engineering courses", Futures, Elsevier Ltd, Vol. 111 No. February, pp. 168-180.

Moura, M.M.C., Frankenberger, F. and Tortato, U. (2019), "Sustainability in Brazilian HEI: practices overview", International Journal of Sustainability in Higher Education, Vol. 20 No. 5, pp. 832-841.

Nyemba, W.R., Carter, K.F., Mbohwa, C. and Chinguwa, S. (2019), “A systems thinking approach to collaborations for capacity building and sustainability in engineering education", Procedia Manufacturing, Elsevier B.V., Vol. 33, pp. 732-739.

Pérez-Foguet, A. and Lazzarini, B. (2019), "Continuing professional education in engineering faculties: Transversal integration of sustainable human development in basic engineering sciences courses”, Journal of Cleaner Production, Vol. 218, pp. $772-781$.

Pohlmann, C.R., Scavarda, A.J., Alves, M.B. and Korzenowski, A.L. (2019), “The role of the focal company in sustainable development goals: A Brazilian food poultry supply chain case study", Journal of Cleaner Production, No. xxxx, p. 118798.

Quelhas, O.L.G., Lima, G.B.A., Ludolf, N.V.-E., Meiriño, M.J., Abreu, C., Anholon, R., Vieira Neto, J., et al. (2019), "Engineering education and the development of competencies for sustainability", International Journal of Sustainability in Higher Education, Vol. 20 No. 4, pp. 614-629.

Quintana-García, C., Benavides-Chicón, C.G. and Marchante-Lara, M. (2020), "Does a green supply chain improve corporate reputation? Empirical evidence from 
European manufacturing sectors", Industrial Marketing Management, Elsevier, No. June 2019, pp. 1-10.

Rampasso, I.S., Anholon, R., Silva, D., Cooper Ordoñez, R.E., Quelhas, O.L.G., Leal Filho, W. and Santa-Eulália, L.A. (2018), “An analysis of the difficulties associated to sustainability insertion in engineering education: Examples from HEIs in Brazil", Journal of Cleaner Production, Vol. 193, pp. 363-371.

Rampasso, I.S., Anholon, R., Silva, D., Cooper Ordóñez, R.E., Quelhas, O.L.G. and Santa-Eulalia, L.A. De. (2019), "Developing in engineering students a critical analysis about sustainability in productive systems", International Journal of Sustainability in Higher Education, Vol. 20 No. 2, pp. 229-244.

Rampasso, I.S., Anholon, R., Silva, D., Cooper Ordoñez, R.E., Santa-Eulalia, L.A., Quelhas, O.L.G., Leal Filho, W., et al. (2019), "Analysis of the perception of engineering students regarding sustainability", Journal of Cleaner Production, Vol. 233, pp. 461-467.

Rampasso, I.S., Siqueira, R.G., Anholon, R., Silva, D., Quelhas, O.L.G., Leal Filho, W. and Brandli, L.L. (2019), "Some of the challenges in implementing Education for Sustainable Development: perspectives from Brazilian engineering students", International Journal of Sustainable Development \& World Ecology, Taylor \& Francis, Vol. 26 No. 4, pp. 367-376.

Raoufi, K., Park, K., Hasan Khan, M.T., Haapala, K.R., Psenka, C.E., Jackson, K.L., Okudan Kremer, G.E., et al. (2019), “A cyberlearning platform for enhancing undergraduate engineering education in sustainable product design", Journal of Cleaner Production, Vol. 211, pp. 730-741.

Schöggl, J.P., Baumgartner, R.J. and Hofer, D. (2017), "Improving sustainability performance in early phases of product design: A checklist for sustainable product development tested in the automotive industry", Journal of Cleaner Production, Elsevier Ltd, Vol. 140, pp. 1602-1617.

Sharma, B., Steward, B., Ong, S.K. and Miguez, F.E. (2017), "Evaluation of teaching approach and student learning in a multidisciplinary sustainable engineering course", Journal of Cleaner Production, Elsevier Ltd, Vol. 142, pp. 4032-4040.

Shokouhyar, S., Pahlevani, N. and Mir Mohammad Sadeghi, F. (2019), "Scenario analysis of smart, sustainable supply chain on the basis of a fuzzy cognitive map", 
Management Research Review, Vol. 43 No. 4, pp. 463-496.

Singh, A.S. and Segatto, A.P. (2020a), "When relational capabilities walk in education for sustainability scenario", Journal of Cleaner Production, Vol. 263, available at:https://doi.org/10.1016/j.jclepro.2020.121478.

Singh, A.S. and Segatto, A.P. (2020b), "Challenges for education for sustainability in business courses: A multicase study in Brazilian higher education institutions", International Journal of Sustainability in Higher Education, Vol. 21 No. 2, pp. 264280.

Stock, T. and Kohl, H. (2018), "Perspectives for International Engineering Education:: Sustainable-oriented and Transnational Teaching and Learning", Procedia Manufacturing, Elsevier B.V., Vol. 21, pp. 10-17.

Tang, K.H.D. (2018), "Correlation between sustainability education and engineering students' attitudes towards sustainability", International Journal of Sustainability in Higher Education, Vol. 19 No. 3, pp. 459-472.

Tejedor, G., Rosas-Casals, M. and Segalas, J. (2019), "Patterns and trends in engineering education in sustainability", International Journal of Sustainability in Higher Education, Vol. 20 No. 2, pp. 360-377.

Tejedor, G., Segalàs, J. and Rosas-Casals, M. (2018), "Transdisciplinarity in higher education for sustainability: How discourses are approached in engineering education", Journal of Cleaner Production, Vol. 175, pp. 29-37.

UN. (2015), "Sustainable Development Goals (SDGs)", available at: https://www.un.org/sustainabledevelopment/sustainable-development-goals/ (accessed 10 October 2020).

UNESCO. (2017), Education for Sustainable Development Goals: Learning Objectives. Education for Sustainable Development. The Global Education 2030 Agenda.

Vanalle, R.M., Ganga, G.M.D., Godinho Filho, M. and Lucato, W.C. (2017), "Green supply chain management: An investigation of pressures, practices, and performance within the Brazilian automotive supply chain", Journal of Cleaner Production, Vol. 151, pp. 250-259.

Zabaniotou, A., Fytili, D., Lakioti, E. and Karayannis, V. (2019), "Transition to bioenergy: Engineering and technology undergraduate students' perceptions of and 
readiness for agricultural waste-based bioenergy in Greece", Global Transitions, Elsevier Ltd, Vol. 1, pp. 157-170.

Zizka, L., McGunagle, D.M. and Clark, P.J. (2021), "Sustainability in science, technology, engineering and mathematics (STEM) programs: Authentic engagement through a community-based approach", Journal of Cleaner Production, Elsevier Ltd, Vol. 279, p. 123715. 